\title{
The practice of everyday oystering: aquaculture as resistance
}

\author{
Adriane K. Michaelis ${ }^{1}$ \\ Donald W. Webster \\ L. Jen Shaffer \\ University of Maryland, USA
}

\begin{abstract}
As members of complex social-ecological systems (SES), fishermen navigate and respond to system changes to maintain their livelihoods. These changes often involve dynamic power relationships. In Maryland (United States), commercial fishermen or watermen demonstrate a history of responding to SES changes, including power relationships in which they often feel restricted. We describe how watermen have historically employed tactics, as conceived by de Certeau (1984), to resist and succeed within a constraining system. We consider involvement in oyster aquaculture as a recent tactic, and compare data from interviews with watermen and non-watermen involved in aquaculture to understand power relationships and adaptations within this SES. Interviews suggest that, while both watermen and non-watermen aquaculturists perceive similar power relations within the system, only watermen begin work in oyster aquaculture as a tactic in response to these relations $(\mathrm{P}<0.001)$. Results illustrate diverse perceptions of power as well as ongoing changes within the SES. More broadly, we introduce the idea of SES adaptations as tactics of resistance and emphasize the need for a more integrative understanding of SES and power.
\end{abstract}

Key Words: Aquaculture, fisheries, power

\section{Résumé}

En tant que membres de systèmes socio-écologiques complexes (SSE), les pêcheurs doivent naviguer et réagir aux changements du système afin de maintenir leurs moyens de subsistance. Ces changements impliquent souvent des relations de pouvoir dynamiques. Dans l'état du Maryland (États-Unis), les pêcheurs commerciaux ou watermen démontrent une longue tradition de réaction aux changements du SSE y compris des relations de pouvoir auxquelles ils ont souvent l'impression d'y être soumis. Nous décrivons comment les watermen ont historiquement employé la tactique, telle que conçue par de Certeau (1984), pour résister et réussir dans un système contraignant. Nous considérons la participation des watermen dans l'ostréiculture comme une tactique récente et nous comparons les données d'entrevues avec des aquaculteurs (watermen et non-watermen) afin de comprendre les relations de pouvoir et les adaptations au sein du SSE. Bien que tous les aquaculteurs perçoivent des relations de pouvoir similaires dans le système, les entrevues suggèrent que seuls les watermen commencent à travailler dans l'ostréiculture comme tactique en réponse aux relations de pouvoir $(\mathrm{P}<0,001)$. Les résultats illustrent diverses perceptions du pouvoir, ainsi que des changements en

\footnotetext{
${ }^{1}$ This work represents doctoral research conducted by Dr. Adriane Michaelis in the Department of Anthropology at the University of Maryland. Presently, she is is a social scientist with ECS in Fairfax, VA, USA. Email: adriane.michaelis "at" ecstech.com. Donald Webster is a Principal Agent with University of Maryland Extension at the University of Maryland, USA. Dr. L. Jen Shaffer is an Assistant Professor in the Department of Anthropology at the University of Maryland, USA. Appreciation and thanks go to the Maryland watermen and oyster growers who took part in this project. We are grateful to Dr. Casey Walsh for editorial assistance throughout the process, as well as to reviewers and Dr. Mark Leone who provided comments on early drafts. Additional thanks go to Roberto Diaz Polgar and Dr. Tom Hilde for assistance with abstract translation. All errors remain our own. This research was supported by the Maryland Sea Grant Coastal Resilience and Sustainability Fellowship (Award No. 026006-001), the National Science Foundation Graduate Research Fellowship Program (Grant No. BCS 1822266), and the University of Maryland Dean's Research Initiative.
} 
cours, au sein du SSE. Généralement, nous introduisons l'idée des adaptations du SSE comme une tactique de résistance, et nous insistons sur la nécessité d'une compréhension plus intégrative du SSE et du pouvoir.

Mots clés: aquaculture, pêche, pouvoir

\section{Resumen}

Como miembros de sistemas socioecológicos complejos (SSE), los pescadores se adaptan y responden a los cambios del sistema para mantener su medio de vida. Estos cambios a menudo implican relaciones dinámicas de poder. En Maryland (Estados Unidos), los pescadores comerciales o watermen demuestran un historial de respuesta a los cambios de SSE, incluidas las relaciones de poder en las que a menudo se sienten damificados. Describimos cómo los watermen han empleado históricamente tácticas, tal como las concibió de Certeau (1984), para resistir y tener éxito dentro de un sistema restrictivo. Nosotros consideramos que la participación en la acuicultura de ostras, es una táctica reciente. Comparamos los datos de las entrevistas con acuicultores (watermen y non-watermen) para comprender las relaciones de poder y las adaptaciones dentro de este SSE. Las entrevistas nos sugieren que, si bien todos los acuicultores perciben relaciones de poder similares dentro del sistema, pero solo los watermen comienzan a trabajar en la acuicultura de ostras como una táctica en respuesta a estas entidades $(\mathrm{P}<0.001)$. Los resultados reflejan las diversas percepciones del poder, así como los cambios en curso dentro del SSE. En general, presentamos la idea de las adaptaciones del SSE como tácticas de resistencia, y enfatizamos la necesidad de una comprensión más integradora del SSE y el poder.

Palabras clave: acuacultura, pesca, poder

\section{Introduction}

Fisheries-based livelihoods form part of particular social-ecological systems (SES), and for individuals with tenuous circumstances, some elements of these systems can restrain their ability to consistently provide for their households. ${ }^{2}$ As part of a complex SES, fishermen respond to biophysical changes like warming waters or storm events, sociopolitical changes such as modifications in regulations and catch limits, and unpredictable population dynamics of their target catch (Dwyer and Minnegal 2006; Ostrom 2009). ${ }^{3}$ These are a few examples of the types of changes that fishermen respond to, and each SES presents unique challenges and opportunities. Though fishermen may not be able to control many SES aspects that affect their livelihoods, they are not powerless against them and act within the system to reduce impacts, risks, or challenges associated with unfavorable SES changes. We describe how one group of fishermen - Maryland watermen - have historically responded to SES changes, with emphasis on power relationships within the SES. ${ }^{4}$ Additionally, we investigate the decision to participate in oyster aquaculture, the cultivation of oysters on privately leased bottom, as a more recent response to a dynamic SES. We incorporate de Certeau's (1984) concept of 'tactics' in considering watermen's decisions to work in aquaculture, aiming to understand whether aquaculture participation is a means of advancing in a restrictive system.

\section{Fishermen's response to a dynamic social-ecological system}

A review of adaptive methods that fishermen employ to respond to social-ecological challenges reveals a variety of common actions. One response may be to suffer losses in catch until the situation improves (Cinner et al. 2009; Perry et al. 2011). Fishermen make do with lower catch and lower income, or find ways to supplement lost income. Livelihood diversification, which involves adding or temporarily switching occupations within and outside of fisheries, is also a common strategy (e.g., Allison and Ellis 2001; Cinner et

\footnotetext{
${ }^{2}$ Social-ecological systems: complex, integrated systems in which humans are part of nature; the study of SES study recognizes links between processes, properties, and entities in social and ecological systems (Berkes et al. 2008; Berkes and Folke 1998).

${ }^{3}$ We use "fishermen" to denote both men and women with fisheries-based livelihoods. This corresponds to participants' self-identification and preferences within North American fisheries (Branch and Kleiber 2015).

${ }^{4}$ As with "fishermen", this group of commercial fishers is referred to as "watermen." Historically and presently a maledominated industry, commercial fishers in Maryland have traditionally been identified as watermen. This is also the term used and preferred by project participants (Michaelis, field data). Additionally, the number of women involved in seafood harvest, as opposed to processing, has increased relative to historic patterns in Maryland (Woolever 2016).
} 
al. 2009; Perry et al. 2011). Another solution may be to permanently exit a fishery, taking on other work (Cinner et al. 2009). Conversely, fishermen may respond by increasing fishing effort (Cinner et al. 2011; Perry et al. 2011) or using more efficient gear to compensate for limited catch (Badjeck et al. 2010; Berkes and Jolly 2002). Geographical mobility, which could involve changing fishing grounds or household migration, is another mechanism to adapt to shifting SES dynamics (e.g., Himes-Cornell and Hoeltling 2015; Nunan 2010; Perry et al. 2011). In some cases, fishermen follow a migratory species or move to an area where target catch exists in higher numbers. Lastly, the presence of resource-sharing networks could be a solution to better withstand unfavorable SES conditions (Berkes and Jolly 2002). Resource-sharing may involve food-sharing, financial support, or even cooperative fishing groups, all intended to help mitigate risks associated with fisheries-based livelihoods. Situation-specific features influence which approach is utilized, but this summary indicates the variety of ways fishermen respond to SES change. Additionally, each riskreducing method falls within the understanding and characterization of general human adaptation processes to SES change (Thornton and Manasfi 2010). The fishermen tactics outlined above represent actions within their immediate means. Such actions offer fishermen an opportunity to respond to stressors beyond their control, affording them agency and the ability to exercise power against a perceived stronger force. As will be expanded upon below, the notion of power within a SES shapes the understanding of these actions as tactics rather than simply adaptive responses.

While SES literature provides a starting point to conceptualize the integration and network-like characteristics of the systems that fishermen act within (Benessaiah and Sengupta 2014; Berkes et al. 2008; Nayak and Berkes 2012; Turner et al. 2003), the use of an SES approach to understand power relations within such a system has been more limited (Béné 2003; Fabinyi et al. 2014). This lack of attention is problematic, as social inequities, power imbalances, and social and environmental injustices can be catalyzed and exacerbated when system attributes change (Nayak et al. 2016). Thus, understanding social relations of power within a SES is essential to comprehend the effect of systemic inputs and shifts (Armitage et al. 2012; Béné 2003; Crépin et al. 2012; Haller and Merten 2008; Jentoft and Midré 2011; Lenton 2013; Walker and Meyers 2004). Here, we adapt the complexity inherent in a SES approach to understand power dynamics within an example system.

\section{Understanding power in fisheries}

Power dynamics within fisheries are understudied (Jentoft 2007; Nayak et al. 2016). Understanding fishermen's perceptions of power within a SES is enhanced by political ecology, which examines the role of power relations in human access to, use of, activity in, and benefits from the environment (Biersack 1999). Discussions of power via the lens of political ecology highlight multiple ways to frame analyses, and demonstrate its ability to integrate such perspectives (Svarstad et al. 2018). As SES change, so do power relations, understood by a variety of different methodologies and research approaches (Nayak et al. 2016). This article extends political ecological discussions and conceptions of power and does so with emphasis on an expanding private fishery in the United States.

Questions of access to resources and representation, privatization, neoliberalism, and capitalism are key to understanding the political ecology of contemporary fisheries SES (Altamirano-Jiménez 2017; Barnett et al. 2017; Bennett 2017; Lalancette 2017). Unequal power relations are visible and result in some actors being marginalized, for example among distant fishing nations and coastal developing countries; fishermen on smaller boats rather than industrial vessels; peasant fishermen, in relation to local elites; and among boat owners and crew (Song et al. 2018). Studies investigate the impacts of privatization and catch-share programs, revealing differential benefits and amplified inequity among groups (e.g. Bavington et al. 2004; Bodwitch 2017; Chambers et al. 2017; Donkersloot 2016; Hoefnagel and de Vos 2017; Knott and Neis 2017; McCormack 2017; Olson 2011; Scholtens and Bavinck 2018). The same is true of work that aims to describe power in co-managed fisheries, where there are persistent concerns about knowledge integration, social class formation, and disempowerment of small-scale fishermen (Davis and Ruddle 2012; Quimby and Levine 2018). The inclusion or absence of local SES knowledge in fisheries decision-making is also influenced by power relationships (Campling et al. 2012; Jentoft 2017; Verelst 2013). In this article, we take a different look 
at power and fisheries privatization. We describe a shift toward a privatized oyster fishery, and how power relations have both influenced and been affected by that SES. This novel integration of power and SES analyses contributes to both SES and political ecology.

It is important to understand power as dynamic, relational, and occupying unexpected places, including the SES that fisheries are a part of (Ahlborg and Nightingale 2018). We consider locations of power as identified by watermen and oyster aquaculturists, but do so by building upon de Certeau's (1984) concept of tactics. Tactics, as described by de Certeau (1984), are actions carried out by the "ordinary man" as a means of resistance within an oppressive or constraining system. Within their everyday life and through their daily actions, individuals regularly manipulate the territory of more powerful others. They operate within a system, using its rules and products, but in a different way to that intended by the creators of the system. In some cases, they also operate with different motivations and strategies. In addition, consumers (in this case of seafood and fish, fishing gear and boats) employ tactics to "use" the "products imposed by a dominant economic order" (de Certeau 1984, p. xiii). These "tactics of consumption" are ways that "the weak make use of the strong" and add a "political dimension to everyday practices" (de Certeau, 1984, p. xvii).

One example of a tactic as described by de Certeau is the way that Indigenous people responded to Spanish colonization in the Americas. Though Indigenous groups adapted to Spanish cultural practices, de Certeau (1984) suggests that they "made of the Spanish rituals, representations, and laws imposed upon them something quite different from what their conquerors had in mind" (p. xiii). Tactics need not be in response to such blatant power dynamics as colonization. They can be employed against other "everyday" powers, for example through the consumption of advertisements. The consumer has control over how the advertisement may be read or heard, and what actions it inspires, if any. De Certeau sees such everyday practices as tactics and a type of resistance, allowing the weak to make use of the strong in their everyday actions. He uses the example of la perruque, or a worker "borrowing" company time while disguising it as work for his or her employer. A contemporary example of la perruque might be someone scanning social media at work while they pretend to be doing something for their employer on the computer. These underscores the idea that tactics may be employed in response to a range of forms of oppression, subjugation, or power differentials. Many are commonplace and do not necessarily carry the same weight as typically associated with the term 'oppression.'

Tactics are in a constant state of reassessment and correction. They are opportunistic and seized momentarily. They involve a degree of artistry or cunning and are "dependent upon possibilities offered by circumstances" (de Certeau, 1984: 30). Tactics are used to manipulate a space but are not defined by it. Strategies, on the other hand, create the space or system. In fisheries, adaptive methods may exist as tactics in response to shifting SES power relationships. As with de Certeau's tactics, these responses are regularly reassessed as circumstances and opportunities change. These tactics are a less recognizable form of resistance, which can take shape as adaptation or "making do" with dynamic power relationships. Tactics are often smallscale, and as such, they are not unlike those in Scott's (2008) Weapons of the Weak: everyday actions carried out by people resisting class-based oppression. Tactics often represent subtle resistance, rather than outright rebellion or systemic and structural changes.

We present a case based in the state of Maryland (United States), where watermen demonstrate repeat use of tactics in an attempt to succeed in a constraining system. The system in which watermen must act, however, expands de Certeau's notion of the powerful. Watermen employ tactics against state and federal regulators, wealthy landowners, voters, and even public opinion - all sources of power identifiable in a de Certeau-ian sense. Watermen also respond to another, arguably more powerful entity, the biophysical environment, often referred to as simply "Mother Nature" by participants. Here, the integration of power and SES theories is key. Biophysical constraints of the system, i.e., Mother Nature, represent another power relation that watermen have little influence over, but must make do with. In this case, the biophysical environment is a driver behind the need to employ tactics. Introducing the idea of Maryland's oyster fisheries as part of a SES presents a different way of considering tactics and adaptive responses, and emphasizes relational power dynamics within Maryland fisheries. 
In the sections that follow, we outline the interplay of power relationships within the SES that watermen are part of. Combining literature review and empirical research, we propose and detail the historical tactics employed by watermen and explore a possible current tactic, participation in oyster aquaculture. Oyster aquaculture is an expanding industry in Maryland and watermen's involvement may be a tactic to succeed within the system. We show how aquaculture has become a tactic and the implications for the socialecological system. Further, we explore the difference between tactics, opportunities, and adaptations as they relate to participation in oyster aquaculture.

\section{The social-ecological system and power within Maryland oyster fisheries}

The Chesapeake Bay is a large estuary on the eastern coast of the United States and is habitat for a diversity of flora and fauna able to withstand variable salinity, temperature, and oxygen extremes (Figure 1). These tolerant species include commercially important blue crab (Callinectes sapidus), clams (Mya arenaria, Mercenaria mercenaria, and Tagelus plebeius), eel (Anguilla rostrata), menhaden (Brevoortia tyrannus), striped bass (Morone saxatillis), and eastern oyster (Crassostrea virginica). The oyster is an ecologically, economically, culturally, and politically important species and the focus of this case study.

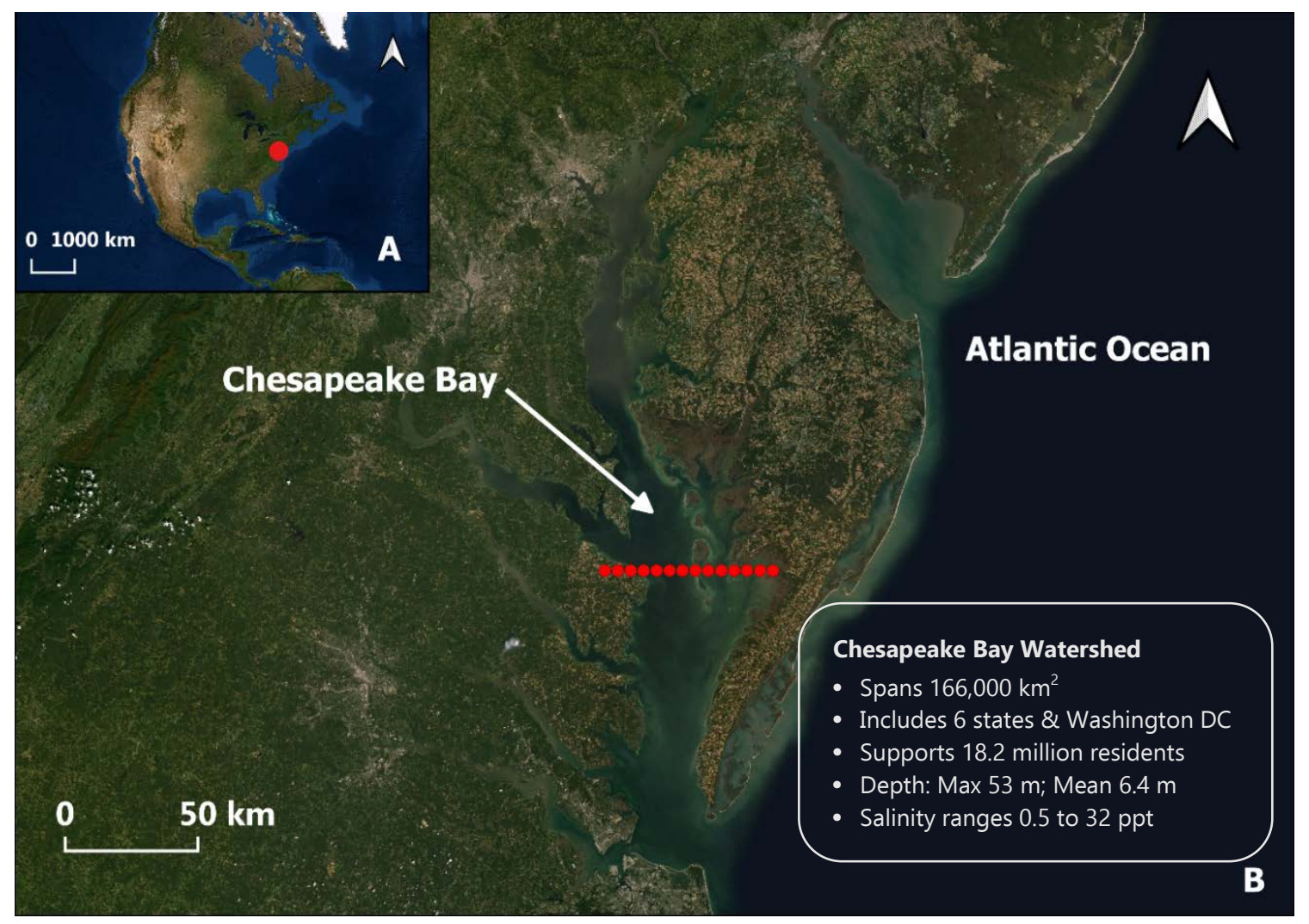

Figure 1: Chesapeake Bay. The inset (A) shows the location of the Chesapeake Bay in North America. The main image (B) shows the geography and scale of the bay, along with general watershed metrics (Chesapeake Bay Program 2019). The red dashed line represents approximately the Maryland-Virginia state border. Waters north of the line are managed by the state of Maryland. The Potomac River, which forms the Maryland-Virginia border on the western shore, is managed by the Potomac River Fisheries Commission rather than an individual state. (Map created using QGIS 2019). 
Maryland has a wild harvest oyster fishery and a privatized oyster aquaculture industry. Oyster bottom in the Chesapeake Bay and Atlantic coastal bays is categorized and mapped according to three designations: 1) the Public Shellfish Fishery Area (PSFA), 2) a no-harvest sanctuary, and 3) oyster aquaculture leases. PSFAs are the bottom that licensed watermen with oyster harvest surcharge permits can harvest oysters from according to gear and size restrictions during the wild season. Oyster sanctuaries are bottom protected from harvest (MD DNR 2019d). Oyster aquaculture lease is bottom that has been individually applied for and issued a permit through state and federal governments to allow for private cultivation of oysters either directly on bottom or in off-bottom containers (Code of Maryland Regulations [COMAR] Section 08.02.23.02). The territorialization of bay bottom for public and private use has old and new elements. Regulatory tension between public and private oyster fisheries and bottom classification has existed since the early 1800s. and involves a series of bills intended first to expand and then restrict oyster aquaculture (Figure 2).

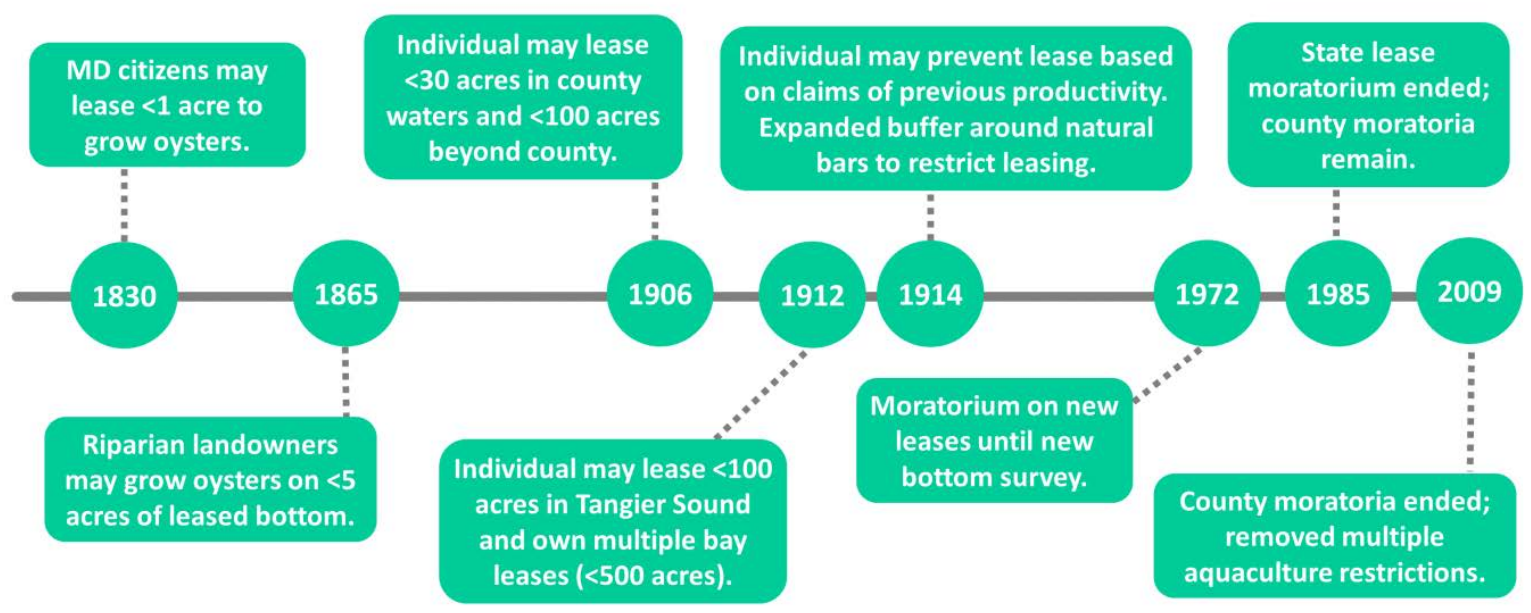

Figure 2. Timeline of Maryland oyster aquaculture policy. Policy related to Maryland shellfish aquaculture has vacillated with efforts to expand aquaculture opportunities countered by restrictive legislation (Brooks 1891; Code of Maryland Regulations [COMAR] Section 08.02.23.00; Keiner 2009; Kennedy and Breisch 1983).

Shifts in oyster territories and production have implications for other fisheries. Oysters provide a number of ecological benefits and, in this way, more oysters in the water through aquaculture and restoration contribute to a healthier bay and fisheries overall (Beck et al. 2011; Coen et al. 2007). They provide water filtration, food and habitat for other animals, shoreline stabilization, and enhancement of other fisheries (Beck et al. 2011). In the Chesapeake, shellfish have been noted to improve water clarity through the removal of suspended solids, which also enables seagrass growth (Newell 2004). Shellfish also reduce the nutrient load in the Chesapeake's eutrophic waters (Newell et al. 2005). As habitat, oysters enhance other fisheries, like blue crab and striped bass, which contribute to Maryland's coastal economies (Grabowski and Peterson 2007). Oyster aquaculture is known to provide similar benefits and services (e.g., Bricker et al. 2017; Dumbauld et al. 2009; Forrest et al. 2009; Humphries et al. 2016; Shumway et al. 2003). Expanded sanctuaries and leased bottom, however, may enhance conflict over bottom use with other fisheries, recreational users, and waterfront property owners, as will be discussed below. 


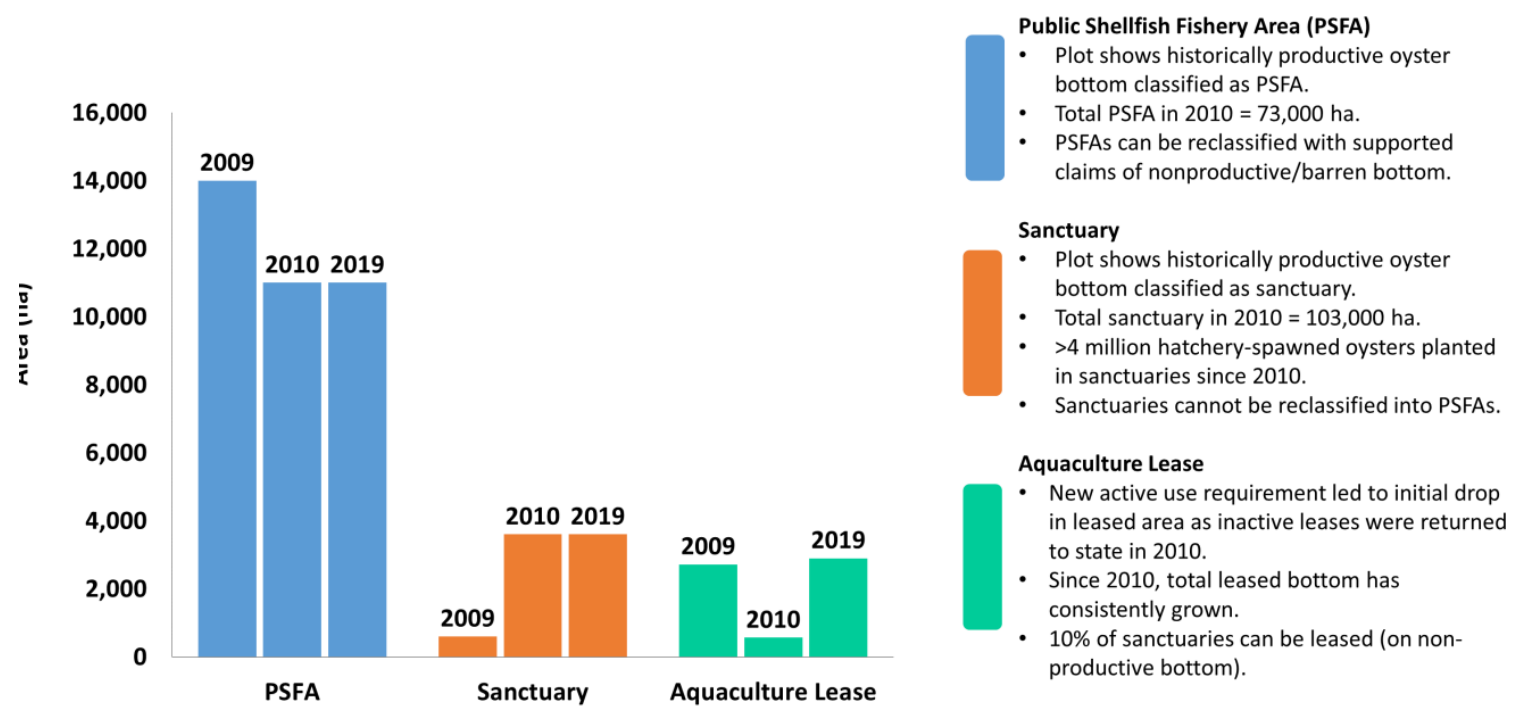

Figure 3: Effect of 2009 policy changes on oyster bottom designation. When 2009 legislative changes took effect in 2010, PSFA was reduced, sanctuaries expanded, and leased bottom initially decreased, but has consistently grown (Green and Tracy 2013; MD ACC 2019; MD DNR 2016, 2019c, 2019d).

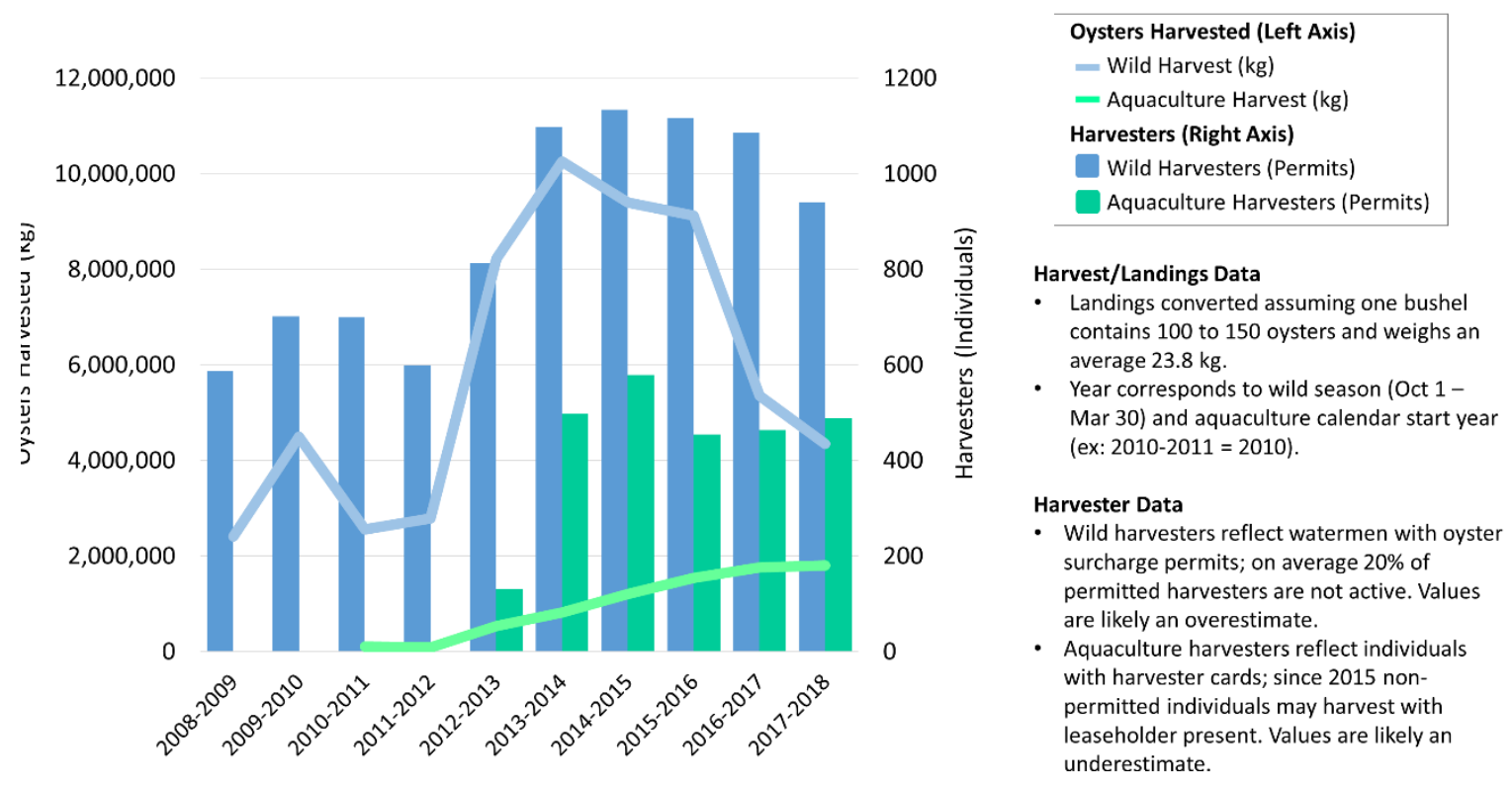

Figure 4: Oyster production and activity. Lines show harvest totals for Maryland wild (upper/blue) and aquaculture (lower/green) oysters. Aquaculture data are not available for years prior to 2010. Columns depict the number of harvesters involved in each industry, though these numbers are likely overestimates for active wild harvesters and underestimates for active aquaculture harvesters (MD ACC 2019; MD DNR 2019b). 
The watermen have largely opposed aquaculture industry development. Opposition took the form of limited involvement in aquaculture as well as political lobbying through local representatives, which resulted in a number of policy changes as outlined in Figure 2 (Brooks 1891; Code of Maryland Regulations [COMAR] Section 08.02.23.00; Keiner 2009; Kennedy and Breisch 1983). Watermen opposed aquaculture development with three concerns:

1) some did not believe oysters could be successfully grown on barren bottom,

2) privatization of the oyster industry would grant more power to packing house owners and large corporations, and

3) loss of the wild fishery would be akin to a loss of heritage (Keiner 2009; Kennedy and Breisch 1983).

The first of these concerns is gone, but the latter two persist to varying degrees: 2) concerns of power relate to individual leaseholders rather than packing houses or corporations, and 3) fears related to loss of the wild fishery are generally connected to how the wild fishery has been managed, regardless of aquaculture (Michaelis, field data). Two centuries of vacillating oyster policies suggest that watermen are not without power in the way fisheries are managed, as they have successfully stalled or hindered aquaculture expansion multiple times. Instead, we see that power is dynamic and occurring in a constant tension. As we will show, however, watermen often feel restricted in various power relationships. Historically, Maryland watermen have carried out a range of tactics that allow them to adapt, survive, and even thrive in a constraining system. Tactics enable a way to reclaim power or affect the power relationship toward the favor of watermen.

\section{History of watermen tactics}

To detail the historical use of tactics by watermen, we consider narratives centering on Chesapeake watermen. These narratives, for the most part, were not written by watermen, though some incorporate watermen interviews and discussions. Our intent is not to create another narrative, but reinterpret the existing collection in the context of tactics. Through these collective narratives, one can glimpse an innovative and opportunistic group who have exhibited an array of tactics. Such everyday acts are forms of resistance and ways that watermen make do, and showcase the adaptability that characterizes the group (Jacoby 1991; Van Dolah 2018). It is important in understanding that, in identifying tactics, watermen actions may seem especially self-serving. This may be so, but tactics are a means of resisting dominant power structures and are thus a way for those limited in power to subvert the system.

\section{Harvest methods}

Harvest methods represent a way that watermen use tactics to work within a structured management system on a daily basis, and include type of catch, travel, and gear. The type of catch harvested varies seasonally based on regulations and stock. Watermen may not have the freedom to fish anything at any time, but can work within the system and shift to a different species if they choose. Watermen may also travel to new areas to harvest. ${ }^{5}$ Different sites may require different gear. With oysters, watermen can be licensed to harvest using a power or sail dredge, patent tongs, shaft tongs, or dive (MD DNR 2019a). Each gear type is restricted to certain areas, but watermen have the option of switching gear and sites if one is not meeting their goals.

The history of the towed dredge is interesting when considering gear choice as a tactic. Upon collapse of New England's oyster stocks in the early 1800s, New England oystermen brought dredge boats to the Chesapeake (Alford 1973). Maryland watermen motivated legislation in 1820 that eliminated out-of-state harvesters and what they considered a bad harvest practice; dredging remained illegal until after the Civil War (Dudley 2010). At that time watermen began dredging and, although there was contention over dredge sites,

\footnotetext{
${ }^{5}$ Restrictions limiting watermen from harvesting outside of county-of-residence waters were removed in 1971 after a member of the Tangier Sound Watermen's Association, with a county delegate, challenged the regulation. (Bruce v. Director, 261 Md. 585, 587 [Md. 1971]).
} 
the dredge expanded as common oyster harvest gear (Image 1). This shifting perspective on dredging highlights the fluidity of tactics and how watermen have benefited through their use. Through the exclusion of out-of-state fishing fleets, watermen were able to restrict access to oyster stocks, and eventually adopt much more efficient harvesting practices themselves. The impact of the dredge as a harvest practice continues to be debated but warrants additional study, as many scientists indicate its destructive nature on reef and bottom topography, while many watermen argue its role in unearthing buried shell to provide clean substrate for oyster spat to settle upon (Michaelis, field data).

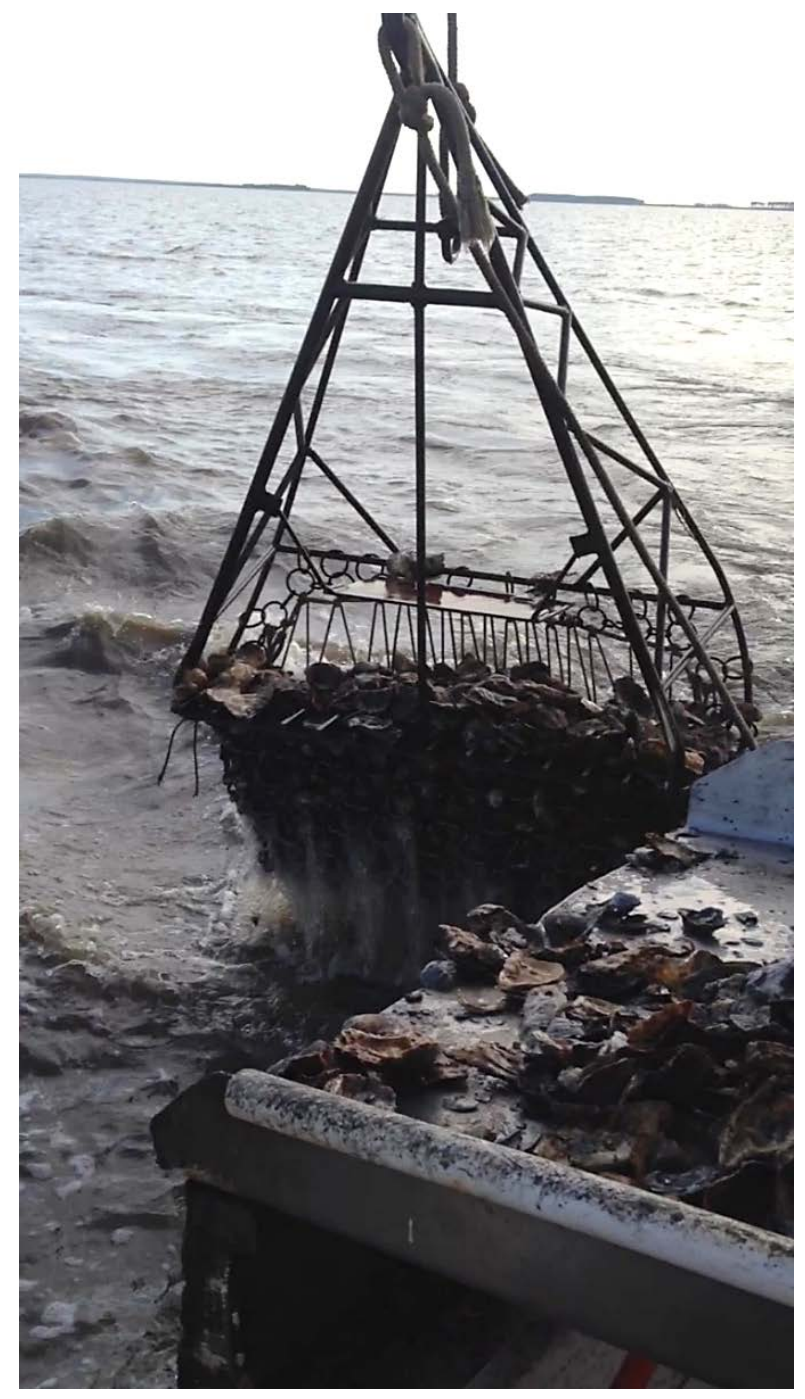

Image 1. Oyster dredge hauling oysters. The towed dredge continues to be used to harvest oysters both in the wild fishery and on some aquaculture lease sites in Maryland.

\section{Oyster Wars}

During the latter part of the $19^{\text {th }}$ century, the oyster boom inspired a scramble to harvest oysters and watermen within Maryland and throughout the Chesapeake battled with each other over harvest rights. Narratives of the Oyster Wars portray watermen as pirates, who "revel[ed] in the violence" (Healey 2010: 97). The rush to harvest and associated violence was so extreme that the state implemented the Oyster Navy, a predecessor of today's Natural Resource Police, to combat piracy on the water (Wennersten 1981). Work on 
the water became increasingly dangerous, leading locals to refuse to take on oyster work during this time (Wennersten 1981). In turn, watermen sought crews in New York and Philadelphia, where men were "kidnapped and intimidated by brass knuckle and pistol" (Wennersten 1981: 55). This led to the forced labor of many German, Irish, and Italian immigrants, who often did not return to shore (Wennersten 1981). Even the most negative practices during this time might be considered tactics. One could argue that watermen's actions were a means of resisting a system enforced by the state, which restricted economic possibilities by limiting harvest area, gear, and opportunity. This is not an appealing spot of oyster history, but demonstrates a way that watermen subverted the system. Captains made do, and sought profit in a management system that they found repressive.

\section{Poaching}

A tactic used by watermen that is deliberate subversion of the system is the poaching of non-target species, catch outside of size limits, or harvest in closed areas. This is not standard practice - a small subset of watermen participate in this sort of activity, but those who do may be reacting within a system that they feel has disadvantaged them. Often poaching is purported by restoration researchers to occur in no-harvest sanctuaries - in areas that were once PSFAs (Michaelis, field data). Illegal harvest within a sanctuary may represent a directed action against the state or system who closed the PSFA. Additionally, poaching of wild oysters is often difficult to enforce or charge, particularly if unreported. This is reminiscent of Scott's discussion of poaching in formerly common forests that details "popular complicity", where individuals were reluctant to identify poaching in areas that were previously free access (Scott 2008). Resource managers recognize poaching as a directed action against them; thus, poaching is a tactic that does not go unnoticed and is readily identified as resistance (Calvert 2016; MD DNR 2014; Northam 2016; Rentz and Wheeler 2015).

\section{Religiosity}

A less obvious tactic may be religiosity. Ernst (2003) describes watermen as "pious, with church attendance high, and absence from Sunday service not only noticed, but likely to raise sincere concerns within the congregation" (p. 90). Stories describe the role of Methodism after the Revolutionary War in "taming" the bay's "wild and rebellious watermen", suggesting that there was a change in character with the spread of Methodism (Wennersten 1981: 11; Wolf 1986). Watermen, along with their eastern shore communities along the Chesapeake, readily adopted Methodism as it was introduced by Joshua Thomas (Wallace 1906). The adoption of Methodism can be considered a tactic, offering a means of securing community support. Religious participation may improve adaptive capacity through building a larger social network to fall back on if needed (Miller Hesed and Paolisso 2015; Van Dolah 2018). Methodism, and religion involvement overall, enables watermen to draw upon community support and experience a greater ability to "make do" during lean times.

\section{Integration}

One consideration of watermen's tactics relates to integration tendencies. During the Revolutionary War, watermen sided with the British because of "their hatred for Maryland's slave-holding rebel gentry" (Wennersten 1981: 8). Narratives tell stories of integrated crews that raided American ships and bayside plantations, liberating slaves as they moved (Wennersten 1981). This was not necessarily motivated by an opposition to slavery outright, but a means of resisting a powerful group of people that watermen had felt slighted them (Wennersten 1981). During the Civil War, landowner resentment continued, and watermen staked their views to present themselves as contrary to landowners, siding with the Union. Following the war, working the water was one of the best-paying jobs for a freed black man (Dudley 2010; Wennersten 1981). Narratives cite the lack of a "color line" and the early integration of freed men into water work (Wennersten 1981). In towns like Cambridge, white watermen and oyster packers worked side-by-side with black men and women, upsetting some of Dorchester County's upper class (Wennersten 1981). Dredging crew statistics illustrate the integration of the oyster industry, with 2,107 white men and 1,453 black men employed on large dredge boats between 1869 and 1870 (Wennersten 1981). While a positive step in civil rights, integration was also a tactic for captains - they wanted the best crews in order to maximize profits. 


\section{Politicking}

Narratives suggest a political adaptability throughout the history of Chesapeake watermen. Watermen as an entity may not side with a certain political party, and if they do, that association is typically not permanent (Ernst 2003). Watermen have practiced precise politicking to further their interests. This is highlighted in a case already mentioned, where watermen sided with the British during the Revolutionary War. This alliance was a means of rebelling against landowners, but was also advantageous economically. During the Civil War, watermen professed loyalty to the Union, but maintained illegal commerce with the Confederacy (Wennersten 1981). In this way, watermen were able to play both sides, while never truly aligning with one or the other. Legislatively, though watermen comprise a small number of constituents relative to the entire state, narratives suggest that they possess a great deal of political power, as evidenced in the history of oyster policy. Bills passed during the early 1900s alternately promoted the development of oyster aquaculture or hindered its progress. Watermen were the driving force behind bottom reclassification and barren bottom contestations in the early 1900s (Kennedy and Breisch 1983). Their political power was reduced by the state apportionment of 1964, but watermen continue to exhibit influence in policymaking (Ernst 2003).

\section{Shaping discourse}

Environmental discourse surrounding Maryland fisheries management tends to be dominated by scientific values and views, contributing to feelings of disregard for watermen (Paolisso 2002; Paolisso 2006; Van Dolah 2018). Watermen, however, are not absent from this discourse. Pitted against sanctuaries and closures, watermen use imagery and associations connected to heritage to promote narratives of the waterman as an endangered species or vanishing livelihood, highlighting how, as a group, they are regularly disempowered (Van Dolah 2018). This is connected to politicking, but as a tactic represents a way that watermen are able to work themselves into a discourse that they have largely been excluded from. Narratives identify a nostalgia for the Chesapeake's past, and a concern the region's waterfronts will continue to transform in a way that makes it more challenging to maintain a livelihood on the water (Blackistone 2001; Dudley 2010; Ernst 2003 Jacoby 1991; Sherwood 1994). Capitalizing on this concern is one way that watermen have contributed to discourse surrounding oyster management. Though they do not argue against conservation or resource protection, and in fact point out that they are the last who wish to see the resource gone, watermen promote the idea that the community identity associated with a wild fishery is also valuable.

\section{Aquaculture?}

More recently, the incorporation of oyster aquaculture into one's livelihood portfolio may be a tactic on its own. In the new research and discussion that follows, we investigate why watermen have elected to start growing oysters and if it is in response to some form of perceived power relation or systemic constraint.

\section{Methods}

\section{Data collection}

Between June 2016 and September 2018, we interviewed 57 oyster aquaculturists as part of a project to understand participation in Maryland aquaculture. ${ }^{6}$ In this article, 'waterman aquaculturist' refers to watermen participants in the project who are also involved in oyster aquaculture $(\mathrm{N}=28)$. 'Non-waterman aquaculturist' refers to participants who did not work the water as a source of income prior to aquaculture $(\mathrm{N}=29)$. To solicit participants, we used snowball sampling, beginning with participants with whom we had established relationships due to prior work. In order to gain broad representation from all aquacultureproducing counties as well as a diverse group in terms of age and gender, we asked participants for general and specific recommendations to meet these sampling goals. In total, nine of Maryland's coastal counties were represented; of the four counties and city not represented, only one has the practical potential for oyster

\footnotetext{
${ }^{6}$ At the time of interviews, all 57 participants were permitted harvesters. Thus, they represent $13 \%$ of the approximately 450 permitted harvesters at that time.
} 
aquaculture based on water quality. The majority (86\%) of participants were male and participants represented a range of ages: 18-30 years old (14\%), 31-40 (23\%), 41-50 (25\%), 51-60 (26\%), and 61 or older $(12 \%)$.

Semi-structured interviews did not target themes of power, but focused on factors that motivated individuals to participate in aquaculture or avoid it. Interview themes included: environmental change; ecological function; economic investment and stability; heritage and identity; oyster management, policy, and enforcement. Although power relationships were not the intended focus of the project, interview responses frequently mentioned ways that participants were restricted by aspects of the SES and reflected the concept of tactics. As such, we felt that this was an important theme to analyze and especially because it was introduced without prompting from targeted interview questions. We audio-recorded, transcribed, and used a combination of open and grounded coding to analyze interviews.

\section{Coding and data analysis}

We coded interviews to identify examples of 1) perceived power relations and 2) oyster aquaculture employed as a tactic. Within this first code type, we focus on the perception of power as described by watermen and non-watermen aquaculturists. The initial open-coding analysis revealed six common power relations within this SES: 1) biophysical environment, 2) competition with other fisheries, 3) paperwork, 4) public opinion, 5) state and federal regulations, and 6) wealthy Marylanders (detailed in Table 1). We subsequently re-coded data to more specifically identify these six power themes. Themes reflect the continuously strained power relationships shared by watermen and non-watermen aquaculturists, and our analysis elucidates distinctions and conceptions of these connections.

\begin{tabular}{|l|l|}
\hline Power Relation & Description \\
\hline Biophysical Environment & $\begin{array}{l}\text { Ways participants are constrained by the biophysical environment. This includes } \\
\text { weather, water quality, disease, natural oyster population, etc. }\end{array}$ \\
\hline Competition with Other Fisheries & $\begin{array}{l}\text { Ways participants suggest another fishery receives privilege over theirs or restricts } \\
\text { their success. }\end{array}$ \\
\hline Paperwork & $\begin{array}{l}\text { Ways participants are restricted by paperwork, permits, etc. (the actual process } \\
\text { rather than regulation or legislation). }\end{array}$ \\
\hline Public Opinion & $\begin{array}{l}\text { Ways participants are restricted due to public opinion, narratives, press, other } \\
\text { groups, etc. }\end{array}$ \\
\hline Regulations & Ways participants are restricted by local, state, or federal regulations. \\
\hline Wealthy Marylanders & Ways participants are restricted when wealthy residents are privileged. \\
\hline
\end{tabular}

Table 1. Perceived power relations in Maryland fisheries, as identified by aquaculturists.

\section{Statistical analysis}

We used chi-square analyses to compare frequency of mention of each power relation between participant groups as well as the overall mention of a power relation by participants. To test for differences among power relations for all participants as well as within each participant group, we ran Cochrane's $Q$ analyses with paired McNemar tests. To test whether one group (watermen or non-watermen) was more likely to use aquaculture as a tactic, we used a chi-square analysis to identify differences in the frequency of 
mention of aquaculture as a tactic between participant groups. We completed all statistical analyses using $\mathrm{R}$ statistical software with $\alpha$ equal to 0.05 (R Core Team 2018).

\section{Results}

Most participants discussed some perceived power relation that contributed to feelings of repression (N: 20 of 29 non-watermen aquaculturists and 24 of 28 watermen aquaculturists), but the frequency of mention of power relations overall did not differ between groups. Analysis of all participants revealed differences in the frequency of mention of each power relation $(\mathrm{P}=0.002$; Figure 5$)$ and pairwise comparisons indicated two groups: competition, public opinion, and wealthy Marylanders were not different from one another (identified by "A" in Figure 5), nor were biophysical environment, paperwork, regulations, and wealthy Marylanders (identified by "B" in Figure 5). In these statistical groupings, Group B power relations were mentioned more frequently than Group A; wealthy Marylanders as a power relation was not significantly different from either group and thus represents an overlapping relation.

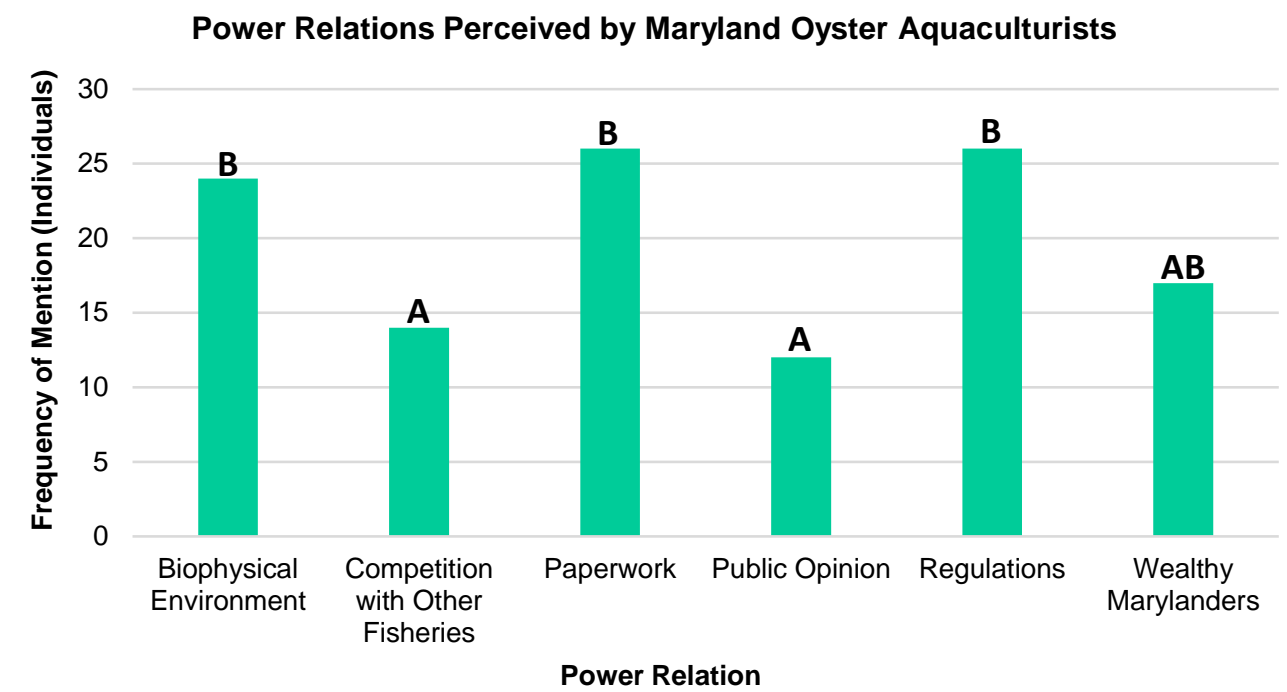

Figure 5. Power relations perceived by Maryland oyster aquaculturists. Data include responses from both participant groups. Differences in perceived power relations were apparent among all participants $(\mathrm{P}=0.002)$. Pairwise comparisons revealed two groupings (denoted by $\mathrm{A}$ and $\mathrm{B}$ above).

Within each participant group, no significant differences in power relation mentions were observed (Figure 6). Chi-square analyses comparing mentions of each relation between groups also yielded no significant differences. 


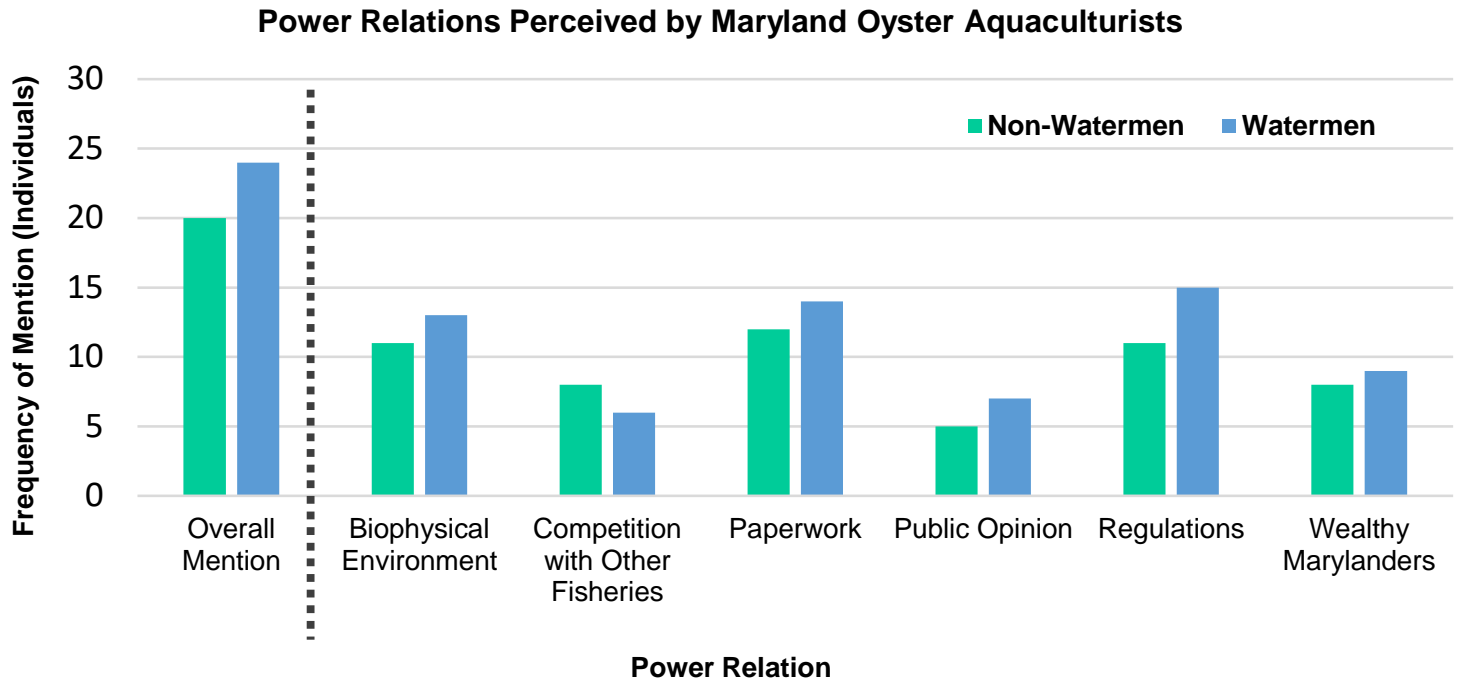

Figure 6: Power relations perceived by Maryland oyster aquaculturists by participant group. No significant differences in power relation mentions within or among each participant group were observed.

Of those interviewed, 21 participants discussed aquaculture as a response to some type of oppressive power relation, and thus we consider their involvement in aquaculture a tactic. In other words, if a participant cited one of the six noted power relations as a reason to enter aquaculture, it was recognized as a tactic. Watermen aquaculturists ( $\mathrm{N}$ : 18 of 28) were more likely to discuss their participation in oyster aquaculture as a tactic than non-watermen aquaculturists (N: 3 of 29; $\mathrm{P}<0.001$; Figure 7).

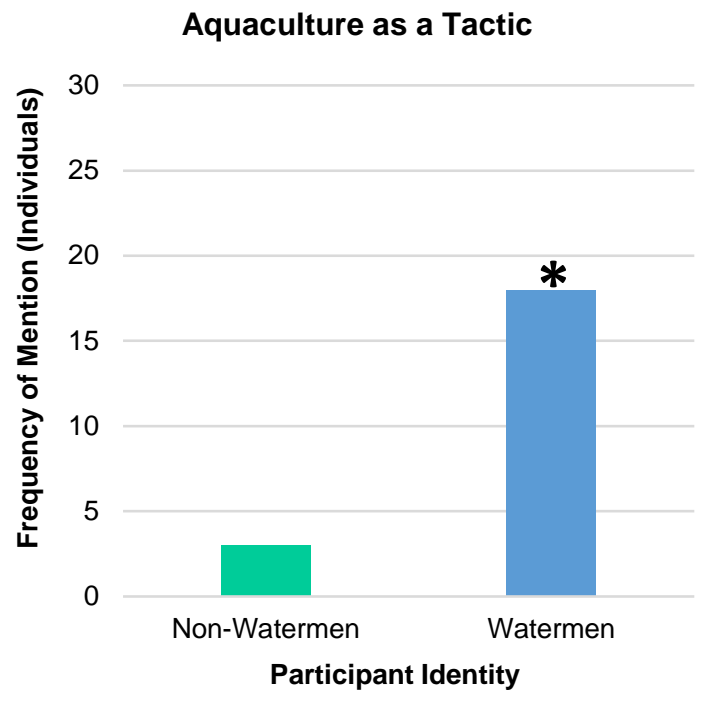

Figure 7: Aquaculture as a tactic. Watermen were more likely to describe their involvement in aquaculture as a tactic or response to a power relation than non-watermen $(\mathrm{P}<0.001)$. 


\section{Discussion}

Maryland oyster aquaculturists are part of a dynamic SES. Since the 2009-2010 regulatory changes, the status of Maryland's oyster fisheries and harvesters has changed. These changes involve a reduction in available bottom for public harvest, an expansion in no-harvest sanctuary areas, and an increase in bottom actively used for oyster aquaculture. Not surprisingly, oyster production has shifted since 2010, most notably with an increase in the number of oysters produced via aquaculture as well as an increase in the number of individuals growing and harvesting aquaculture oysters. Aquaculture supporters hope that increased aquaculture production paired with oyster restoration activities will contribute to better overall bay health, emphasizing the suite of ecosystem services provided by oysters. Interview data suggest that in the midst of SES changes, Maryland oyster aquaculturists perceive various sources of repression in the system and these power relationships are experienced by both non-watermen and watermen aquaculturists. Data show that some power relations were more frequently mentioned than others, with the biophysical environment, paperwork, regulations, and wealthy Marylanders most often discussed. Though frequency of mentions did not differ within or between groups, it is valuable to understand more about power relations.

\section{Biophysical environment}

Watermen and non-watermen had similar concerns regarding the biophysical environment. Many respondents felt that they were vulnerable, whether they were involved in a wild oyster fishery or oyster aquaculture, but they thought that aquaculture offered a slightly better means to respond. Watermen cited 'Mother Nature' for the present state of wild fisheries, though they also emphasized that management played a part in the current status of marine resources. All participants voiced concerns about the future of their livelihoods because of unpredictable biophysical conditions and the prospect of major storms. Storms have concerted impacts on oysters because they can drastically affect salinity and contribute to increased sedimentation and runoff. Participants also shared worries about the effect of oyster diseases like dermo (Perkinsus marinus) and MSX (Haplosporidium nelsoni), which rainfall patterns also influence. The uncertainty and inability to control aspects of the biophysical environment represent an atypical source of power relative to most power discussions.

Everybody's fundamental problem is Mother Nature. But it currently seems naïve to me to think that we'd have any effect on Mother Nature or that she'd pay any attention if we fussed to her.

- Non-waterman Aquaculturist

Although the biophysical environment was not mentioned more than most of the other power relations, this was the one that participants felt they had the least ability to respond to. Aquaculturists attempted to gain traction by planning oyster planting accordingly with typical rainfall patterns; however, many shared examples of storm events thwarting such plans. For a number of watermen aquaculturists, adding aquaculture to their livelihood portfolio was one means of gaining ground against the biophysical environment. While they still could not control weather events and associated mortality, it offered an additional level of livelihood diversification and stability.

\section{Competition with other fisheries}

Both watermen and non-watermen discussed conflict over bottom, and concerns that other fisheries were privileged over aquaculture. At the same time, participants discussed how aquaculture may restrict bottom use by other fisheries, underscoring the fluidity of this particular power relationship. Most often issues related to the clam fishery, but trotlining for blue crab and concerns that PSFA was being targeted for aquaculture were also mentioned. Some aquaculturists described lease protests based on these conflicts, suggesting that protesters were not being honest with regard to the location of their fishing grounds. Many, though frustrated with the challenge of siting a lease that would not receive protests, acknowledged and were 
sympathetic to the fact that wild harvesters need to work also. Multiple participants, while involved in aquaculture, were also active in the wild clam, crab, and/or oyster fisheries.

It was put very matter-of-factually at one of our meetings that a guy was trying to get a hundred acres of shoreline, where the clammers work every year ... and one of the clammers spoke up and said, 'you're asking about 10 individuals who clam to put their living aside for you. And every trotliner that works through here to put his living aside. For you.'... that played a big role in my approach for [site-selection of my] second lease.

- Waterman Aquaculturist

Still, multiple participants voiced worries that watermen would protest any lease, regardless of fishery conflict. This worry was based on watermen's fear that if they did not take action now to restrict aquaculture expansion, in the future they would have no recourse to retain PSFA. Another type of competition mentioned by non-watermen was concern that market saturation would eventually lead to challenges among aquaculturists in both trying to sell product and acquire new leased bottom.

In discussing competition with other fisheries (Image 2), some participants attempted to respond to this power relation by selecting lease sites that would be of little interest to other fisheries. This was not always effective, but was an attempt to influence the existing power relationship. Some reached out to watermen involved in fisheries likely to protest, to seek input and discuss site selection prior to lease application, again with varying success. Many participants ultimately settled protests with mediators, lawyers, and civil proceedings, which in addition to using time and potentially money, can also affect existing power relations.

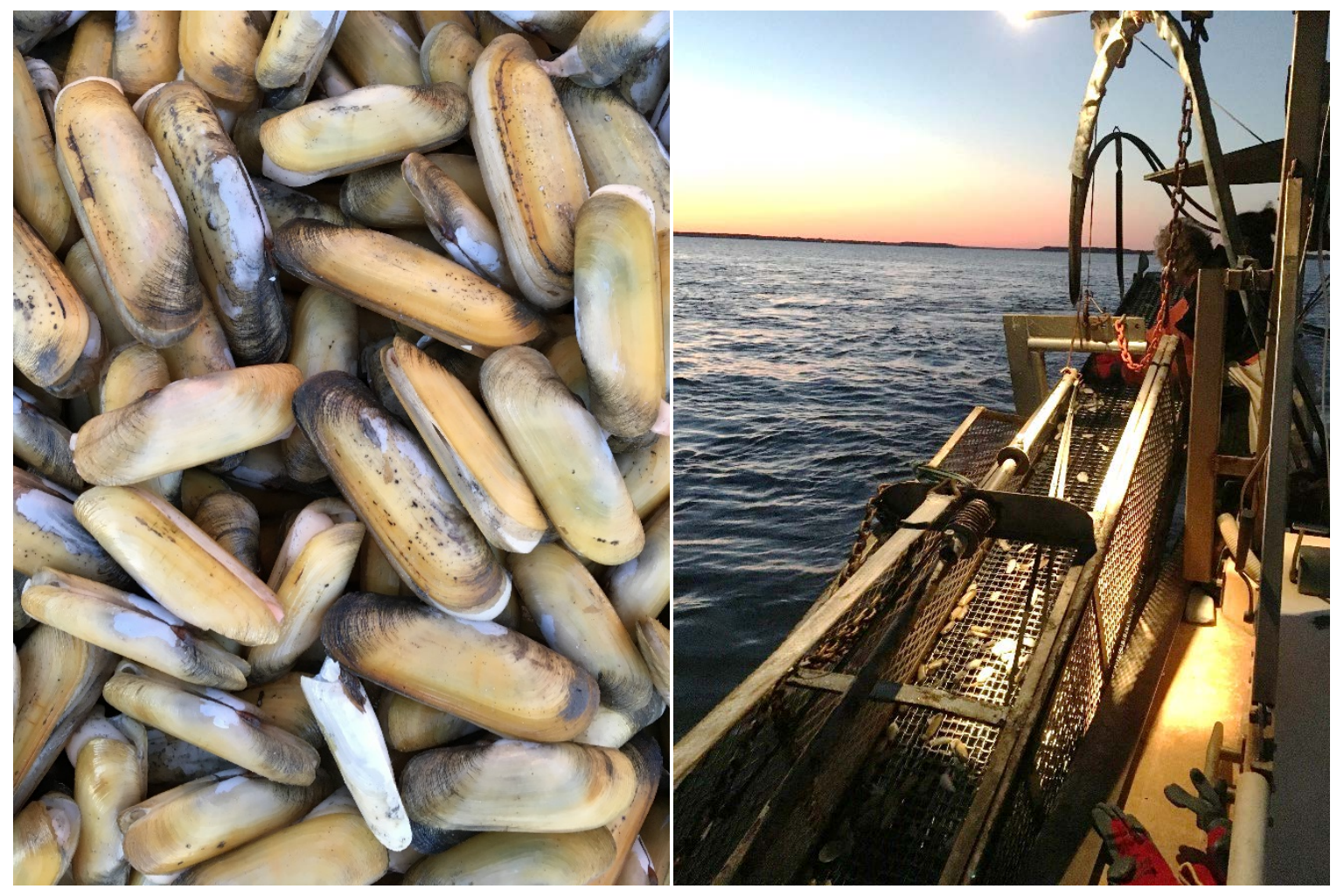

Image 2: Maryland watermen harvesting razor clams. Stout razor clams (T. plebeius; left) support a relatively small, but important fishery in Maryland and are harvested using a hydraulic escalator dredge (right). 


\section{Paperwork}

The amount of paperwork involved in the application process, as well as maintenance of various permits and harvest records upon lease approval, was regularly cited as a way that aquaculturists are restricted. Though connected to federal and state regulations, the time involved in record upkeep and the lease application process received such attention that it warranted its own theme. Watermen and non-watermen held similar views, and both mentioned paperwork as a likely barrier to others entering the aquaculture industry. Participants discussed the number of forms, multiple hoops, and length of time involved in applying for a lease, citing that for the average person, the waiting period is financially prohibitive and an obstacle to entry.

I'll use the term 'chutes and ladders' for how the lease experience was. All total it took about three years. I want to say the first two years I'd go over to the [Department of Natural Resources] ... and I always got sent home with some homework to do...think about this, or you're going to have to include this on your form. Where are you going to get gear? Where are you going to get your oyster seed? What type of oyster are you going to harvest? What type of gear are you going to use? Kind of all of these variables. And it was good, but you know, looking back on it, I feel like if someone would have sat with me for half an hour and gone through it, we could have narrowed that two-year chutes and ladders drill ... down to about a week.

- Non-waterman Aquaculturist

Participants also discussed the repetitiveness or duplicity involved in the paperwork and reports to maintain their lease. Though acknowledging that the process has improved since 2010, most would like to see it more streamlined. Watermen noted that there are recurring fees, licensures, and tags involved in wild harvest as well, suggesting that there is no avoiding them, at least in fisheries. Aquaculturists are limited in their ability to respond to this power relation, but multiple participants mentioned their own tactic of repeated contact with state offices.

\section{Public opinion}

Both participant groups felt restricted by public opinion. Misinformation and limited understanding of oyster aquaculture contributes to an inaccurate public image of the industry and amplifies the number of protests. Ultimately, multiple protests with waterfront property owners were resolved once landowners realized what the proposed lease would entail. Watermen experience a double level of oppression when it comes to public opinion, often mentioning that the public and particularly 'environmentalists' view them negatively. Watermen defend their position, offering that they are the last ones who wish to see the oyster population overharvested.

I went up to [the university] and I...didn't even want to tell them that I worked on the water...I guess it kind of leaked out...and it did feel like they kind of looked at me differently. Some of the people in the room. And I don't know if that's just the stigma or whatever, but then there were a lot of questions toward me. They kind of look at you like you're doing something illegal. Or that your interests are different.

- Waterman Aquaculturist

To combat or shift negative public opinion, some participants are increasingly promoting their sustainable shellfish industry via social media or through available media outlets. This, however, demands time, energy, and at times financial resources. For instances when public opinion led to protests, multiple participants attempted to resolve conflicts with information and discussion. In some cases that was sufficient, in other cases prolonged legal measures were needed. 


\section{Regulations}

Participants discussed restrictive regulations both as they affect them in the wild harvest and in aquaculture. In the wild fishery, watermen felt that there are so many regulations, a wild harvester is unable to make a living, and they expect that restrictions will only increase. This sentiment was shared not only for the oyster fishery, but also striped bass. Regulations motivated many watermen interviewed to enter the aquaculture industry, though with some hesitancy.

I had enough money saved where I had enough to buy a workboat and go gill-netting...or grow oysters ... and I basically saw myself fishing 'til I was 40 years old and being regulated out by the federal government. I saw this as a way of continuing to work the water and I guess have a future. There's a future in this. I think there's a future in this anyway.

- Waterman Aquaculturist

Participants discussed many ways they felt aquaculture regulations were restrictive, citing the abundance of regulations and that many were not appropriate to aquaculture (instead relevant to the wild fishery). Regulatory topics mentioned include the active use requirement and how it could be more pragmatically applied, challenges connected to interstate seed and larvae sales, and the precision of water quality measurements that impact harvest closures. Other issues mentioned have seen improvements since interviews were conducted, including changes to harvester card requirements and the ability to enforce theft from leases. Health-related regulations were generally not mentioned as restrictive. The option that participants cited as a means to respond to regulations was also one of the ways they are restrained. Participants discussed the need to be vigilant and aware of impending legislation, which offers them the opportunity to defend themselves and their industry, but adds another responsibility to their role. In this way, watermen and non-watermen must navigate the political and legislative system to prevent further restrictions.

Every year we wind up going to [the state capital] because there's a bill that gets introduced ... that has the potential to be harmful to the industry... And every year for the last 4 years or so we've had to go, as a young industry, and go up to [the state capital] to testify.

- Non-waterman Aquaculturist

\section{Wealthy Marylanders}

Wealthy Marylanders were discussed in several ways as part of power dynamics in the region. Specific to watermen, wealthy Marylanders were thought to be the ones driving legislation. Participants voiced concerns about wealthy waterfront property owners restricting the ability to have a lease, as well as impeding work in the public fishery. Repeated protests by landowners were viewed as even more oppressive because of the drain of resources required for the prospective leaseholder and the state. This trend inspired some aquaculturists to target more remote locations for their lease sites. These leases were often more difficult to access for aquaculturists, but reduced the likelihood of protests.

I think we'll have less trouble with these two leases than if you were in the middle of the Severn River with million-dollar mansions ... and they all believe that's their water. And their yachts are sailing up and down on it. It's a playground. [They] don't want to make a living here, [they] play with [their] million-dollar yachts.

- Non-waterman Aquaculturist 
Some participants, particularly watermen, mentioned wealthier Marylanders as the group that they thought the state was interested in for its aquaculture industry. Both participant groups expressed fears that wealthy Marylanders would acquire available bottom and prevent new growers from entering the industry.

The everyday person isn't gonna get real strong at it, and that's all I am is an everyday waterman. I don't have millions of dollars to play with, and that's the only thing I can see wrong with [it]. The state might enjoy having a wealthy person get involved so they don't have to deal with everyday whoever, watermen. If they can get somebody that's got a few million dollars to play the game and got a lot of power...sometimes I feel that that's who they're looking for.

- Waterman Aquaculturist

Participants respond to this power entity by being adaptable, in terms of lease siting, how they practice aquaculture, and how they interact with wealthy Marylanders. Some discussed adjusting lease boundaries or moving to a different site to appease waterfront property owners. Others tailored their markers and equipment to be as invisible as was practical.

If [the property owners] would have just [kept dragging] it out, there would be a good chance I never would have got this lease. They know what they're doing. And I don't blame them. I wouldn't want a whole lot of buoys out in front of my house, either. You know, so I told him, 'hey, I'll throw six different colored buoys out there you tell me which one you can barely see and I'll cut it in half and then cut it in a quarter again. If that makes you happy.' You gotta bend with everything.

-Waterman Aquaculturist

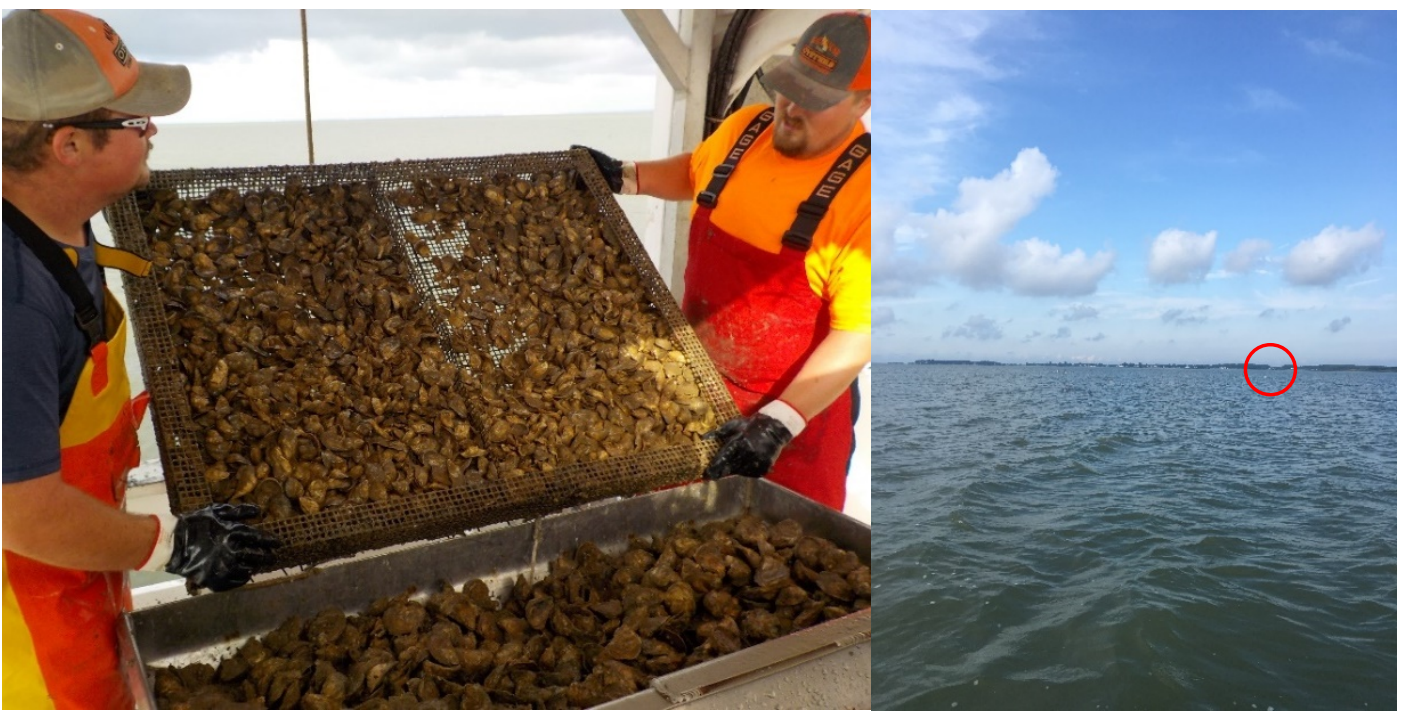

Image 3: Example of an oyster lease. The majority of aquaculture leases in Maryland involve oysters and gear that are submerged, even at low tide. Here, a bottom cage is pulled to sort oysters (left), and be returned to the lease site marked by low-profile buoys (right). The red circle highlights one floating buoy of five in the image. 
Interviews illustrate that watermen and non-watermen aquaculturists alike negotiate power relationships within daily activities in their SES. Though each group's experience with power relations may be slightly different, all participants express concern that they are fighting power relations that afford them limited control. Still, participants act to manipulate settings in their favor. In addition, the adaptability discussed as a means to respond to each power relation provide further examples of tactics.

\section{Aquaculture as a tactic}

Interview data support the idea that watermen are participating in aquaculture as a tactic. The way that watermen described their reasoning for entering the oyster aquaculture industry aligned with de Certeau's concept of tactics more so than with non-watermen $(\mathrm{P}<0.001)$. For the most part, non-watermen aquaculturists did not discuss their involvement in aquaculture as a means to succeed in an oppressive system, even if they did experience similar forms of restriction as watermen aquaculturists. Instead, non-watermen aquaculturists discussed aquaculture as a financial opportunity that provided some sort of additional benefit relative to their other or previous work. Watermen discussed aquaculture as a tactic in a variety of ways. For many, even with its paperwork and regulation, aquaculture represents a livelihood with less state oversight because it is something that the state is promoting. The ability to work the water and be less supervised was appealing. In this sense, they are doing what they think the overarching power wants them to do, but driven by a desire to interact less with the state.

I'm finally doing something they want me to do. Because they're trying to shut me down from everything else I've been doing. I'm finally doing something they like. And they don't bother me. I just do my thing and make sure my paperwork is filled out.

$$
\text { - Waterman Aquaculturist }
$$

Others described their decision to enter the aquaculture industry as a financial one. This decision, however, was not because they saw themselves getting wealthy in oyster aquaculture, but instead because they did not see a long-term option in current fisheries work. Several cited state-supported loan opportunities as a sign that aquaculture was the future and the wild fishery may not exist much longer. Similarly, others got involved in aquaculture because they feared that, as the wild oyster fishery declines, they may miss an opportunity to get a lease. This understanding fits in with the idea of tactics, as it shows watermen reassessing their SES and seizing aquaculture as a new option.

You know why you don't see any dinosaurs around? They couldn't adapt. And that's what I'm doing. I'm adapting. The technology is there, so what do you do? I'm not going to ride a horse, I'm going to [drive] a car. So that's what's happening. And I don't think it's going to end with a wild fishery.

- Waterman Aquaculturist

Some watermen took on aquaculture to fill the down time between different wild seasons, but it is not, nor do they expect it to be, their major source of income. Many are still active in the wild oyster fishery, and in this way working in aquaculture is a particular tactic. They have joined the state-promoted activity of oyster aquaculture, but by staying in the wild harvest, are doing so in a way that is not quite what the state had in mind. ${ }^{7}$ They have diversified their livelihood portfolio with the addition of oyster aquaculture.

\footnotetext{
${ }^{7}$ As part of "Maryland's 10-point Oyster Restoration Plan", one aim of regulatory changes in 2009-2010 involved a shift in commercial oyster production from wild fisheries to private aquaculture (MD DNR 2010).
} 
I'm not going to stop doing everything else...in hopes that this is going to be the only thing that I have to do. Aquaculture. But...maybe eventually, hopefully, you can get a few more weeks out of the year that you can work. You can get a few more months. And just see where it goes.

- Waterman Aquaculturist

Many watermen have taken on aquaculture as a means to succeed within the system, but have not taken it on with enthusiasm. As such, they are again demonstrating a motivation different from what those who created the system intended with the inclusion of watermen in oyster aquaculture.

It's lemonade out of lemons, but it's very bitter. It's like lemonade with no sugar in it. It's better than the lemon, but it ain't much better.

- Waterman Aquaculturist

For many watermen, oyster aquaculture is viewed as the only long-term option to continue working on the water, and aquaculture may afford slightly more agency or ability to react to circumstances than wild fishing. Participants indicated that they thought that the wild oyster fishery was headed towards closure, or at least towards becoming uneconomic. Watermen are using aquaculture as a tactic to succeed or resist in a system that has historically constrained them, shifting power relationships in their favor. Socio-politically, aquaculture and sanctuary oyster sites appear to be privileged, and the tactical response by watermen makes sense. Non-watermen aquaculturists may also be trying to gain advantage, but it is not historical oppression that has inspired them to grow oysters; the current difficulties they experience are linked to their participation in the trade, not something they experience prior to entering the industry. For watermen, although they continue to experience shifting power relations and perceived subjugation, aquaculture provides a means to 'make do' as de Certeau might describe it. Aquaculture allows watermen to continue earning income off the water.

\section{Conclusion}

This case study and discussion has detailed how Maryland's watermen perceive and have responded to historic and recent changes to social-ecological systems, and changing power dynamics. In considering the recent expansion of oyster aquaculture in Maryland, watermen involved in aquaculture have manipulated and reacted to power, as have non-watermen. We considered these individual reactions to SES change through the lens of tactics, and how such responses may be a means of advancing in an otherwise restrictive system. It is noteworthy that power dynamics were not an intended theme of the project interviews. The frequency of its mention, however, and the relevance to this discussion of SES change, underscore the need to look closely at the political ecology of power.

Our study shows that Maryland watermen experience feelings of oppression, through their involvement in wild fisheries and in oyster aquaculture. How then, is participation in oyster aquaculture a 'tactic?' Tactic do not reallocate power to make the individual, the 'everyday man', the dominant power relation in the system. Instead, tactics are ways that an individual can manipulate the system to their advantage, but they are still constrained by it. Historically, watermen have demonstrated use of tactics to advance their interests and keep up with an ever-changing SES. Participation in aquaculture is a recent livelihood response in Maryland fisheries, similar to Scott's 'Weapons of the Weak' (2008). Watermen are not upending the system through their participation in aquaculture; however, this and other historic tactics demonstrate subtle acts of resistance. These acts might go unnoticed, but ultimately are ways that watermen are working within the system, making use of its rules and roles, in order to enhance their own success. This success may not be undertaken exactly in the manner that the 'producers' of the system intended, which supports the idea of a tactical, innovative response. 
Several watermen discussed their participation in aquaculture as a form of adaptation. Though it is accurate to say that watermen are adapting, adverse power relationships constrain livelihood adaptations and tactical responses. The data suggest that many watermen have adopted aquaculture as their tactical response. For non-watermen, activity in aquaculture is neither tactic nor adaptation, but instead an opportunity, given the power relationships of Maryland's wild fisheries in which they had less previous involvement. They are taking advantage of the opportunity not to alter an oppressive relationship, but to make money. In other words, both watermen and non-watermen aquaculturists are seizing an opportunity, but participation by watermen is tactical, rather than purely opportunistic.

In considering aquaculture as both a tactic and adaptation, it is important to keep in mind that adaptation is not always positive. Coulthard (2012) suggests that people can adapt to undesirable circumstances, but that does not necessarily mean that well-being or quality of life has improved because of that adaptation. In the case of Maryland aquaculture, additional research to investigate the associated impacts on well-being would be beneficial in understanding the implications of these livelihood changes. Likewise, short-term adaptation may not yield long-term success, as with some of the distinctions and connections between incremental and transformative adaptation as detailed in climate adaptation literature (e.g., Hadarits et al. 2017; Kates et al. 2012; Roggema et al. 2012). Further exploration into the financial effectiveness of these tactics is also warranted. Is the addition of aquaculture a temporary coping mechanism for watermen? Will it yield long-term success as a SES adaptation? At the time of this project, many participants were within the first five years of their aquaculture enterprise. Future work investigating long-term success and economic viability would also be valuable to better understand the utility of such a tactic.

In the future, if this SES continues on the current track, these discussions of power relations highlight the continued path of aquaculturists' tactics. Aquaculturists do not see themselves as powerful relative to other system entities, and have already begun to act in order to affect power relations. As an SES changes, power is in constant flux. At the present time, aquaculture may afford a greater sense of agency and power for those involved relative to the wild harvest, but aquaculturists are still part of a larger SES where they are not in full control. When considering the implications of aquaculture as a tactic for the SES, we might predict that more watermen will carry out this tactic, expanding aquaculture in Maryland and expanding their participation in it. This has occurred even over the course of this research project, as watermen interviewed at the beginning who were not active in aquaculture are now applying for or have acquired leased bottom (Michaelis, personal observation). The history of Maryland watermen and tactics presented here, however, highlights that the SES is not static; power is not static; tactics are not static. Instead, tactics and power relationships will continue to change along with the SES.

The study reveals the way that fishermen within a particular SES perceive and respond to sources of power, as well as to social and environmental change. It contributes to understanding in-situ experiences of power and how actors in an SES consider power relations. The inclusion of the biophysical environment as a power relation broadens the conception of power within a SES. In addition, it introduces the biophysical environment to de Certeau's concept of tactics, and further extends discussion surrounding adaptive methods to respond to SES change. Such an inclusion shows where de Certeau's conception can be refined to better account for a complete SES. Power exists in surprising places. These tactics represent something more than adaptations, because they are adaptations to shifting power. Consideration of adaptive responses as tactics helps to integrate ideas surrounding risk and uncertainty in a SES and in theories of power. As such, this study builds upon the expanding body of political ecology literature exploring power in fisheries, and though we incorporate an older concept related to power, this example shows that the idea of tactics is still relevant in trying to describe how actors can work within an oppressive system. 


\section{References}

Ahlborg, H. and A.J. Nightingale. 2018. Theorizing power in political ecology: the where of power in resource governance projects. Journal of Political Ecology 25: 381-401.

Alford, J.J. 1973. The role of management in Chesapeake oyster production. Geographical Review 63(1): 4454.

Allison, E.H. and F. Ellis. 2001. The livelihoods approach and management of small-scale fisheries. Marine Policy 25(5): 377-388.

Altamirano-Jiménez, I. 2017. "The sea is our bread": Interrupting green neoliberalism in Mexico. Marine Policy 80: 28-34.

Armitage D., C. Béné, T. Charles, D. Johnson and E.H. Allison. 2012. The interplay of wellbeing and resilience concepts in applying a social-ecological systems perspective. Ecology and Society 17(4):15.

Badjeck, M.C., E.H. Allison, A.S. Halls and N.K. Dulvy. 2010. Impacts of climate variability and change on fishery-based livelihoods. Marine Policy 34(3): 375-383.

Barnett, A.J., R.A. Messenger and M.G. Wiber. 2017. Enacting and contesting neoliberalism in fisheries: the tragedy of commodifying lobster access rights in Southwest Nova Scotia. Marine Policy 80: 60-68.

Bavington, D., Grzetic, B., and Neis, B. 2004. The feminist political ecology of fishing down: reflections from Newfoundland and Labrador. Studies in Political Economy 73(1): 159-182.

Beck, M.W., R.D. Brumbaugh, L. Airoldi, A. Carranza, L.D. Coen, C. Crawford ... and H.S. Lenihan. 2011. Oyster reefs at risk and recommendations for conservation, restoration, and management. Bioscience 61(2): 107-116.

Béné, C. 2003. When fishery rhymes with poverty: a first step beyond the old paradigm on poverty in smallscale fisheries. World Development 31(6): 949-975.

Benessaiah, K. and R. Sengupta. 2014. How is shrimp aquaculture transforming coastal livelihoods and lagoons in Estero Real, Nicaragua? The need to integrate social-ecological research and ecosystembased approaches. Environmental Management 54(2): 162-179.

Bennett, A. 2017. The influence of neoliberalization on the success and failure of fishing cooperatives in contemporary small-scale fishing communities: a case study from Yucatán, Mexico. Marine Policy 80: 96-106.

Berkes, F., J. Colding and C. Folke (eds.). 2008. Navigating social-ecological systems: building resilience for complexity and change. Cambridge: Cambridge University Press.

Berkes, F. and C. Folke (eds.). 1998. Linking social and ecological systems: management practices and social mechanisms for building resilience. Cambridge: Cambridge University Press.

Berkes, F. and D. Jolly. 2002. Adapting to climate change: social-ecological resilience in a Canadian western Arctic community. Conservation Ecology 5(2): 18.

Biersack, A. 1999. Introduction: from the "New Ecology" to the New Ecologies. American Anthropologist 101(1): 5-18.

Blackistone, M. 2001. Dancing with the tide: Watermen of the Chesapeake. Maryland: Tidewater Publishers.

Bodwitch, H. 2017. Challenges for New Zealand's individual transferable quota system: processor consolidation, fisher exclusion, and Māori quota rights. Marine Policy 80: 88-95.

Branch, T.A. and D. Kleiber. 2017. Should we call them fishers or fishermen? Fish and Fisheries 18(1): 114127.

Bricker, S.B., J.G. Ferreira, C. Zhu, J.M. Rose, E. Galimany, G. Wikfors ... and R. Grizzle. 2017. The role of shellfish aquaculture in reduction of eutrophication in an urban estuary. Environmental Science and Technology 52(1): 173-183.

Brooks, W.K. 1891. The Oyster. Maryland: Johns Hopkins University Press.

Bruce v. Director, 261 Md. 585 (Md. 1971). 
Calvert, S. 2016. Maryland marine police crack down on oyster poachers. The Wall Street Journal. [Accessed May 13, 2016]. http://www.wsj.com/articles/maryland-marine-police-crack-down-on-oyster-poachers1454841002.

Campling, L., E. Havice and P. McCall Howard. 2012. The political economy and ecology of capture fisheries: market dynamics, resource access and relations of exploitation and resistance. Journal of Agrarian Change 12(2-3): 177-203.

Chambers, C., G. Helgadóttir and C. Carothers. 2017. "Little kings": community, change and conflict in Icelandic fisheries. Maritime Studies 16(1): 10.

Chesapeake Bay Program. 2019. Facts and figures. [Accessed July 17, 2019]. https://www.chesapeakebay.net/discover/facts.

Cinner, J.E., T. Daw and T.R. McClanahan. 2009. Socioeconomic factors that affect artisanal fishers' readiness to exit a declining fishery. Conservation Biology 23(1): 124-130.

Cinner, J.E., C. Folke, T. Daw and C.C. Hicks. 2011. Responding to change: using scenarios to understand how socioeconomic factors may influence amplifying or dampening exploitation feedbacks among Tanzanian fishers. Global Environmental Change 21(1): 7-12.

Code of Maryland Regulations (COMAR) 08.02.23.02. 2010. Department of Natural Resources. Fisheries Service. Shellfish Aquaculture and Leasing. Definitions. [Accessed July 1, 2019]. http://www.dsd.state.md.us/comar/comarhtml/08/08.02.23.02.htm.

Code of Maryland Regulations (COMAR) 08.02.23.00. 2010. Department of Natural Resources. Fisheries Service. Shellfish Aquaculture and Leasing. [Accessed July 1, 2019]. http://www.dsd.state.md.us/comar/comarhtml/08/08.02.23.00.htm

Coen, L.D., R.D. Brumbaugh, D. Bushek, R. Grizzle, M.W. Luckenbach, M.H. Posey ... and S.G. Tolley. 2007. Ecosystem services related to oyster restoration. Marine Ecology Progress Series 341: 303-307.

Coulthard, S. 2012. Can we be both resilient and well, and what choices do people have? Incorporating agency into the resilience debate from a fisheries perspective. Ecology and Society 17 (1):4.

Crépin, A.S., R. Biggs, S. Polasky, M. Troell and A.D. Zeeuw. 2012. Regime shifts and management. Ecological Economics 84: 15-22.

Davis, A. and K. Ruddle. 2012. Massaging the misery: recent approaches to fisheries governance and the betrayal of small-scale fisheries. Human Organization 71(3): 244-254.

de Certeau, M. 1984. The practice of everyday life. California: University of California Press.

Donkersloot, R. 2016. Considering community allocations: Power and the politics of enclosure in the Gulf of Alaska. Marine Policy 74: 300-308.

Dudley, W. 2010. Maritime Maryland. Maryland: Johns Hopkins University Press.

Dumbauld, B.R., J.L. Ruesink and S.S. Rumrill. 2009. The ecological role of bivalve shellfish aquaculture in the estuarine environment: a review with application to oyster and clam culture in West Coast (USA) estuaries. Aquaculture 290(3): 196-223.

Dwyer, P.D. and M. Minnegal. 2006. The good, the bad and the ugly: risk, uncertainty and decision-making by Victorian fishers. Journal of Political Ecology 13(1): 1-23.

Ernst, H. 2003. Chesapeake Bay Blue: science, politics, and the struggle to save the Bay. Maryland: Rowman and Littlefield.

Fabinyi, M., L. Evans and S.J. Foale. 2014. Social-ecological systems, social diversity, and power: insights from anthropology and political ecology. Ecology and Society 19(4): 28.

Forrest, B.M., N.B. Keele, G.A. Hopkins, S.C. Webb and D.M. Clement. 2009. Bivalve aquaculture in estuaries: review and synthesis of oyster cultivation effects. Aquaculture 298(1): 1-15.

Grabowski J.H. and C.H. Peterson. 2007. Restoring oyster reefs to recover ecosystem services. In Cuddington K., J. Byers, W. Wilson and A. Hastings (eds.). Ecosystem engineers: plants to protists. Burlington MA: Academic Press. 
Green, C.M. and T.P. Tracy. 2013. Fostering shellfish aquaculture production in Maryland and other states. Department of Legislative Services. [Accessed July 1, 2019] http://dls.maryland.gov/pubs/prod/NatRes/Fostering-Shellfish-Aquaculture-Production-in-Marylandand-Other-States.pdf

Hadarits, M., J. Pittman, D. Corkal, H. Hill, K. Bruce and A. Howard. 2017. The interplay between incremental, transitional, and transformational adaptation: a case study of Canadian agriculture. Regional Environmental Change 17(5): 1515-1525.

Haller, T. and S. Merten. 2008. "We are Zambians—don't tell us how to fish!" Institutional change, power relations and conflicts in the Kafue flats fisheries in Zambia. Human Ecology 36(5): 699-715.

Healey, D. 2010. Delmarva legends and lore. South Carolina: History Press.

Himes-Cornell, A. and K. Hoelting. 2015. Resilience strategies in the face of short-and long-term change: Out-migration and fisheries regulation in Alaskan fishing communities. Ecology and Society 20(2): 9.

Hoefnagel, E. and B. de Vos. 2017. Social and economic consequences of 40 years of Dutch quota management. Marine Policy 80: 81-87.

Humphries, A.T., S.G. Ayvazian, J.C. Carey, B.T. Hancock, S. Grabbert, D. Cobb ... and R.W. Fulweiler. 2016. Directly measured denitrification reveals oyster aquaculture and restored oyster reefs remove nitrogen at comparable high rates. Frontiers in Marine Science 3: 74.

Jacoby, M. 1991. Working the Chesapeake: Watermen on the Bay. Maryland: Maryland Sea Grant College.

Jentoft, S. 2007. In the power of power: the understated aspect of fisheries and coastal management. Human Organization 66(4): 426-437.

Jentoft, S. 2017. Small-scale fisheries within maritime spatial planning: knowledge integration and power. Journal of Environmental Policy and Planning 19(3): 266-278.

Jentoft, S. and G. Midré. 2011. The meaning of poverty: conceptual issues in small-scale fisheries research. In Jentoft, S. and A. Eide (eds.). Poverty mosaics: realities and prospects in small-scale fisheries. Netherlands: Springer. Pp. 43-70.

Kates, R.W., W.R. Travis and T.J. Wilbanks. 2012. Transformational adaptation when incremental adaptations to climate change are insufficient. Proceedings of the National Academy of Sciences 109(19): 7156-7161.

Keiner, C. 2009. The Oyster question. Georgia: The University of Georgia Press.

Kennedy, V.S. and L.L. Breisch. 1983. Sixteen decades of political management of the oyster fishery in Maryland's Chesapeake Bay. Journal of Environmental Management 16(2): 153-171.

Knott, C. and B. Neis. 2017. Privatization, financialization and ocean grabbing in New Brunswick herring fisheries and salmon aquaculture. Marine Policy 80: 10-18.

Lalancette, A. 2017. Creeping in? Neoliberalism, indigenous realities and tropical rock lobster (kaiar) management in Torres Strait, Australia. Marine Policy 80: 47-59.

Lenton, T.M. 2013. Environmental tipping points. Annual Review Environmental Resources 38: 1-29.

McCormack, F. 2017. Sustainability in New Zealand's quota management system: a convenient story. Marine Policy 80: 35-46.

MD DNR: Maryland Department of Natural Resources. 2010. Maryland's 10-Point Oyster Restoration Plan. [Accessed July 17, 2019]. https://dnr.maryland.gov/fisheries/Documents/RestorationPlanSlideshow.pdf

MD DNR: Maryland Department of Natural Resources. 2016. Oyster Management Review: 2010-2015. Draft Report. [Accessed July 1, 2019]. https://nnr.maryland.gov/fisheries/Documents/FiveYearOysterReport.pdf

MD DNR: Maryland Department of Natural Resources. 2018. A stock assessment of the Eastern Oyster, Crassostrea virginica, in the Maryland waters of Chesapeake Bay. Final Report November 2018. [Accessed July 1, 2019]. http://dnr.maryland.gov/fisheries/Documents/StockAssessment_EasternOysterMD.pdf 
MD ACC: Maryland Aquaculture Coordinating Council. 2019. ACC archived meetings. [Accessed August 18, 2019]. http://dnr.maryland.gov/fisheries/Pages/mgmt-committees/acc-archived-Meetings.aspx

MD DNR: Maryland Department of Natural Resources. 2019a. 2019 Commercial Chesapeake Bay regulations. [Accessed July 10, 2019]. https://nnr.maryland.gov/fisheries/Pages/regulations/bay_regs.aspx

MD DNR: Maryland Department of Natural Resources. 2019b. Commercial landings. [Accessed July 1, 2019]. https://dnr.maryland.gov/fisheries/Pages/oysters/Comm_Landings.aspx

MD DNR: Maryland Department of Natural Resources. 2019c. Draft Maryland Oyster Fisheries Management Plan. [Accessed July 1, 2019]. https://dnr.maryland.gov/fisheries/Documents/draft Maryland Oyster FMP_02_19_2019.pdf

MD DNR: Maryland Department of Natural Resources. 2019d. Sanctuaries. [Accessed July 1, 2019]. https://dnr.maryland.gov/fisheries/Pages/oysters/sanctuaries.aspx

Miller Hesed, C.D. and M. Paolisso. 2015. Cultural knowledge and local vulnerability in African American communities. Nature Climate Change 5(7): 683-687.

Nayak P.K. and F. Berkes. 2012. Linking global drivers with local and regional change: a social-ecological system approach in Chilika lagoon, Bay of Bengal. Regional Environmental Change 14(6): 2067-2078.

Nayak, P.K., D. Armitage, and M. Andrachuk. 2016. Power and politics of social-ecological regime shifts in the Chilika lagoon, India and Tam Giang lagoon, Vietnam. Regional Environmental Change 16(2): 325-339.

NCBO: NOAA Chesapeake Bay Office. 2019. Oysters - fish facts. [Accessed July 10, 2019]. https://chesapeakebay.noaa.gov/fish-facts/oysters.

Newell, R.I.E. 2004. Ecosystem influences of natural and cultivated populations of suspension-feeding bivalve mollusks: A review. Journal of Shellfish Research 23: 51-61.

Newell R.I.E., T.R. Fisher, R.R. Holyoke and J.C. Cornwell. 2005. Influence of eastern oysters on nitrogen and phosphorus regeneration in Chesapeake Bay, USA. In Dame, R.F. and S. Olenin (eds.). The comparative roles of suspension feeders in ecosystems. Netherlands: Springer.

Northam, M. 2016. Maryland man charged with 146 counts of oyster poaching. DelmarvaNow. [Accessed May 13, 2016]. http://www.delmarvanow.com/story/news/local/maryland/2016/03/02/maryland-mancharged-146-counts-oyster-poaching/81213594.

Nunan, F. 2010. Mobility and fisherfolk livelihoods on Lake Victoria: implications for vulnerability and risk. Geoforum 41(5): 776-785.

Olson, J. 2011. Understanding and contextualizing social impacts from the privatization of fisheries: an overview. Ocean and Coastal Management 54(5): 353-363.

Ostrom, E. 2009. A general framework for analyzing sustainability of social-ecological systems. Science 325(5939): 419-422.

Paolisso, M. 2002. Blue crabs and controversy on the Chesapeake Bay: a cultural model for understanding watermen's reasoning about blue crab management. Human Organization 61(3): 226-239.

Paolisso, M. 2006. Chesapeake environmentalism: rethinking culture to strengthen restoration and resource management. Chesapeake Perspectives Monograph Series. College Park: Maryland Sea Grant College.

Perry, R.I., R.E. Ommer, M. Barange, S. Jentoft, B. Neis and U.R. Sumaila. 2011. Marine social-ecological responses to environmental change and the impacts of globalization. Fish and Fisheries 12(4): 427450.

QGIS Development Team. 2019. QGIS Geographic Information System. Open Source Geospatial Foundation Project. http://qgis.osgeo.org

Quimby, B. and A. Levine. 2018. Participation, power, and equity: examining three key social dimensions of fisheries comanagement. Sustainability 10(9): 3324.

R Core Team. 2018. R: A language and environment for statistical computing. Vienna: R Foundation for Statistical Computing. http://www.R-project.org 
Rentz, C. and T. Wheeler. 2015. Oyster poaching continues on Bay despite enforcement efforts. The Baltimore Sun. [Accessed July 17, 2019]. http://www.baltimoresun.com/news/maryland/bs-md-oysterenforcement-20150404-story.html.

Roggema, R., T. Vermeend and A.V.D. Dobbelsteen. 2012. Incremental change, transition or transformation? Optimising change pathways for climate adaptation in spatial planning. Sustainability 4(10): 25252549.

Scholtens, J. and J.M. Bavinck. 2018. Transforming conflicts from the bottom-up? Reflections on civil society efforts to empower marginalized fishers in postwar Sri Lanka. Ecology and Society 23(3): 31.

Scott, J.C. 2008(1985). Weapons of the weak: everyday forms of peasant resistance. New Haven: Yale University Press.

Sherwood, J. 1994. Maryland's vanishing lives. Maryland: Johns Hopkins University Press.

Shumway, S.E., C. Davis, R. Downey, R. Karney, J. Kraeuter, J. Parsons...and G. Wikfors. 2003. Shellfish aquaculture-in praise of sustainable economies and environments. World Aquaculture 34(4): 8-10.

Song, A.M., H. Bodwitch and J. Scholtens. 2018. Why marginality persists in a governable fishery - the case of New Zealand. Maritime Studies 17(3): 285-293.

Svarstad, H., T.A. Benjaminsen and R. Overå. 2018. Power theories in political ecology. Journal of Political Ecology 25: 350-363.

Thornton, T.F. and N. Manasfi. 2010. Adaptation - genuine and spurious: demystifying adaptation processes in relation to climate change. Environment and Society 1(1): 132-155.

Turner B.L., R.E. Kasperson, P.A. Matson, J.J. McCarthy, R.W. Corell, L. Christensen, N. Eckley, J.X. Kasperson, A. Luers, M.L. Martello, C. Polsky, A. Pulsipher and A.M. Schiller. 2003. A framework for vulnerability analysis in sustainability science. Proceedings of the National Academies of Science 100: 8074-8079.

Van Dolah, E.R. 2018. Cultural heritage and climate change adaptation pathways. PhD dissertation. College Park, MD: University of Maryland.

Verelst, B. 2013. Managing inequality: the political ecology of a small-scale fishery, Mweru-Luapula, Zambia. Journal of Political Ecology 20: 14-36.

Walker, B. and J.A. Meyers. 2004. Thresholds in ecological and social-ecological systems: a developing database. Ecology and Society 9(2): 3.

Wallace, A. 1906. The parson of the islands: a biography of the Rev. Joshua Thomas: embracing sketches of his contemporaries and remarkable camp meeting scenes, revival incidents, and reminiscences of the introduction of Methodism on the islands of the Chesapeake, and the eastern shores of Maryland and Virginia. Thomas \& Evans Printing Company.

Wennersten, J. 1981. The Oyster Wars of Chesapeake Bay. Maryland: Tidewater Publishers.

Wolf, B. 1986. Amazing Grace: Smith Island and the Chesapeake Watermen. New York: Macmillan.

Woolever, L. 2016. Waterwomen. Baltimore Magazine. [Accessed April 30, 2020]/ https://www.baltimoremagazine.com/2016/7/11/waterwomen-a-handful-of-heroines-work-thechesapeake-bay/ 